\title{
Distribution, identification and range expansion of the common Asellidae in Northern Europe, featuring the first record of Proasellus meridianus in the Nordic countries
}

\author{
Joanna L. Kemp', Andreas Ballot', Jens Petter Nilssen², Ingvar Spikkeland ${ }^{3}$ and Tor Erik Eriksen'
}

\begin{abstract}
Kemp JL, Ballot, A, Nilssen JP, Spikkeland I and Eriksen TE. 2020. Distribution, identification and range expansion of the common Asellidae in Northern Europe, featuring the first record of Proasellus meridianus in the Nordic countries. Fauna norvegica 40: 93-108.

Two out of the three common Asellidae species in Northern Europe are increasing their ranges, aided by human activities. Here we report the discovery of Proasellus coxalis (Dollfuss 1892) in new areas in Norway and the discovery of Proasellus meridianus (Racovitza 1919) for the first time in the Nordic countries, verified with DNA barcoding. A new, detailed photo-identification guide to Asellus aquaticus Linnaeus 1758, P. coxalis and P. meridianus is presented. In addition to head pattern, attention is drawn to the female pleopods as an easy way to differentiate between the two genera. Then detailed examination of male pleopods 1 and 2 can differentiate between $P$. coxalis and $P$. meridianus. The origins, competitive relationships and potential dispersal mechanisms of the two introduced species and the native $A$. aquaticus are explored. By examining the shipping activity at the small, freshwater port where $P$. meridianus was found, we highlight the great connectivity between many European brackish and freshwater ports and possible pathways for species transfer. The risk of trans-oceanic freshwater to freshwater (not just brackish and saltwater) species transfer through ballast water needs to be better communicated. Proasellus coxalis may have been introduced to the river system of Lake Stokkalandsvatnet together with fish transported in microaquaria used as live bait for fishing.
\end{abstract}

doi: 10.5324/fn.v40i0.3353. Received: 2019-12-03. Accepted: 2020-04-14. Published online: 2020-08-12. ISSN: $1891-5396$ (electronic).

Keywords: Asellus aquaticus, Proasellus coxalis, Proasellus meridianus, invasive, identification key

1. NIVA, Gaustadalléen 21, NO-0349 Oslo, Norway

2. Müller-Sars Society, Div. of Biogeography and Ecology, P.O. Box 170, NO-4952 Risør, Norway

3. Østfoldmuseene, Avd. Haldenvassdragets Kanalmuseum, Postboks 64, 1871 NO-Ørje, Norway

Corresponding author: Joanna L. Kemp

E-mail: joanna.kemp@niva.no

\section{INTRODUCTION}

The loss of regional biodiversity is widely acknowledged to be an ever-increasing problem (IPBES 2018). The world's fauna appears to be becoming more homogeneous. Regional biodiversity is harmed not only by species extinction, but also by the arrival of non-indigenous species. In many cases it is not easy to predict the impact a newcomer will have on original species or systems (Nentwig 2007). While some non-native species undoubtably have hugely harmful effects, the effect of others can be more subtle and even, from particular points of view, beneficial (Davis et al. 2011).

The dangers that some non-indigenous species pose to indigenous freshwater species and ecosystem functioning have been highlighted by several studies (e.g. Nentwig 2007). They stress the dramatic effects that some of these species can have in the recipient environment, such as altering and disrupting the biotic structure of ecosystems, affecting the ecology of other species and pushing species toward extinction.

Several species of freshwater crustacean are expanding their ranges in northern Europe (Galil et al. 2007, Nehring 2002b, Nehring 2005, de Vaate et al. 2002, van der Velde et al. 2002). Two Isopod species, within the genus Proasellus in the family Asellidae, are among these. These are Proasellus coxalis (Dollfus 1892) and Proasellus meridianus (Racovitza 1919) (Nehring 2005). They are expanding into areas where previously only Asellus aquaticus Linnaeus, 1758 has been found.

\section{Past and present distribution}

Asellus aquaticus probably has its ancient evolutionary origins around Siberia and has spread from there to western Europe (Grüner 1965, Valentino et al. 1983, Hidding et al. 2003, Verovnik et al. 2005). It is now the most common and widespread European species of the Asellidae (Vitagliano Tadini et al. 1988, Gregory 2009).

Until recently, A. aquaticus was the only freshwater isopod known from the Nordic countries (Økland 1978). It is widely distributed across Denmark and Finland and across the south and east of Sweden. 
In Norway, it has been recorded frequently in the south east of the country (Økland 1978), with a further hotspot occurring in the Trondheim area (Økland 1978, Artsdatabanken 2019). Across the south and middle of the country, it has a more scattered distribution, predominantly found in lower altitude areas, areas of higher human impact or eutrophy, or reduced acidification (Økland 1978). It has been recorded infrequently in northern Norway (Økland 1978) and Sweden, although the known distribution pattern may in part reflect sampling effort.

Proasellus coxalis is thought to originate from the middle east, north African and southern Europe (Vitagliano Tadini et al. 1988, Hewitt 1999, Schmitt \& Varga 2012). It is a very morphologically and genetically variable and widely distributed species, with many subspecies (Flasarová 1975, 1996, Stoch et al. 1996, Ketmaier et al. 2001, Ketmaier 2002). Over the 20th century, it has spread from the Mediterranean northwards in continental Europe, using the many opportunities provided by the canal network to move between catchments and then disperse down rivers to estuaries (Grüner 1965, Heuss 1976, Herhaus 1977, Post \& Landmann 1994, Tittizer 1996, Nehring 2005, Galil et al. 2007, Nentwig 2007). Populations are now well-established in German (1930s), Dutch (1948) and Belgian (1988) inland waters as well in North Sea estuaries (1987) (Knoben \& Peeters 1997, Nehring \& Leuch 1999, Nehring 2002b, Gollasch \& Nehring 2006, Wouters and Vercauteren 2009, Buschbaum et al. 2012) and the Baltic sea region (Szczecin/Oder-lagoon, Wittfoth \& Zettler 2013). Its spread has been helped by being a euryhaline species, able to tolerate brackish water.

In Sweden P. coxalis was first collected in the mid 1970s (Spikkeland et al. 2013) in Höje Å in Scania, and later the species has been found in Råån and Risebergabäcken in Scania and Halland (Ulf Bjelke pers. comm.). It has never been recorded in the British Isles (Dobson 2013). In 2019, P. coxalis was recorded for the first time in Denmark, in Jylland in the western part of the country (Siegel 2019).

In 2012, Spikkeland et al. (2013) recorded P. coxalis in Norway for the first time. It was found in Stokkalandsvatnet and its outlet (Sandnes, Rogaland), as well as two records from 2014 from the nearby Lutsivatnet in south west Norway (Spikkeland et al. 2013, Artsdatabanken 2019). When Spikkeland et al. (2013) discussed how $P$. coxalis had arrived in Norway, they also saw ballast water as a possibility, with the arrival of animals, perhaps, to Sandnes Harbour and subsequent spreading upstream by, for example, mallard ducks. They felt, however, that $P$. coxalis was more likely to have arrived in that locality through the transport of live animals (fish, crustacea, molluscs) used as fish bait in microaquaria from, for example, central Europe. These microaquaria can contain sediment and plants and therefore the eggs, propagules and early stages of many types of aquatic organism.

In 2019, P. coxalis turned up in a completely different geographical area, from samples in a small stream (Hestehaven) flowing into the brackish lake, Landvikvannet, in southern Norway (Hobæk et al. in press) (Figure 1 and 3).

Proasellus meridianus is the original inhabitant of western Europe (Thienemann 1950) and from there it has spread to the northeast (Grüner 1965, Tittizer 1996, Nehring 2002a). Its spread has been aided by canal networks. In Germany, for example, it is thought to have arrived in the 1930s and to be introduced (Gollasch \& Nehring 2006). Today's range includes much of western and northern continental Europe (Portugal, Spain, France, Belgium, Netherlands, Germany) as well as Switzerland (Wittenberg 2005) and the British Isles (Gregory 2009) and now the first record in the Nordic countries. In the U.K. P. meridianus is present at numerous exposed western coastal and island sites, where A. aquaticus is absent (Gregory 2009). Over much of its western range it is endemic and it is thought to have arrived in U.K. after the last glaciation, even before the arrival of $A$. aquaticus (Williams 1962c).

Messiaen et al. (2010) mention disagreement as to whether the species is southern or western European in origin. However, the suggestion of southern origin appears to originate in a table in Josens et al. (2005), quoting Tittizer et al. (2000). However, it is a misquote. In the original Tittizer article it is described it as originating in Western Europe.

\section{Identification}

The arrival of a new species to a country is easy to miss and the spread of the Asellidae demonstrates this. A. aquaticus was previously the only species found in many European countries, meaning that, in the order Isopoda, there was only one aquatic species, making identification possible with almost no examination of the specimen. Although P. coxalis was first recorded in the Netherlands in 1978, it was later discovered in samples retained from 1948 (Wouters and Vercauteren 2009, Knoben \& Peeters 1997). Similarly, Wouters and Vercauteren (2009) discovered the species in Belgium in 2005 and subsequent analysis of stored samples showed it had been present in the country since at least 1998 (Messiaen et al. 2010, Thierry Vercauteren pers.com.). In Denmark it took a determined amateur naturalist, unfamiliar with what she was "supposed" to see, to find $P$. coxalis (Siegel 2019). In Norway P. meridianus was missed in 2015, before being recorded in 2019.

If routine monitoring is to pick up new taxa, there needs to be both an awareness that new species may be arriving and a means to identify them. The Freshwater Biological Association's guide to Identifying Invasive Freshwater Shrimps and Isopods does this for the U.K. (Dobson 2013). It mentions the isopods Jaera istri (Veuille 1979) and Caecidotea communis (Say 1818), but does not include P. coxalis. The currently available identification guides either do not cover all three species in detail or are not in English. None are photoguides. The otherwise detailed FBA Malacostraca key does not include $P$. coxalis (Gledhill et al. 1993). Wouters and Vercauteren (2009) provide a very useful summary table describing how to quickly separate the three species, but limited photos or diagrams, making it less accessible to people unfamiliar with the characteristics. Huwae and Rappé (2003) include the three taxa, but is not easily available and is in Dutch. Henry and Magniez (1983) published a detailed and informative key with excellent diagrams and ecological notes, covering over 20 species of the Asellidae (including rare and subterranean species) for French speakers. Grüner (1965) provides something similarly thorough for German speakers.

Flagging up anthropogenic species spread can help to inform policy and preventative action and the photoguide presented here (Appendix 1) will make this easier for the common Asellidae.

\section{Aim}

The aims of this study are to update the current known distribution of the three non cave-dwelling freshwater isopod species found in northern Europe (Asellus aquaticus, Proasellus coxalis and Proasellus meridianus) and report the first record of $P$. meridianus in the Nordic countries. We will examine the mechanisms and pathways by which the Proasellus species may have arrived in Norway from overseas. We provide, for the first time, a comprehensive photographic identification guide (appendix 1), to make it easier to follow the spread of these species. 


\section{MATERIALS AND METHODS}

Study areas: Stokkalandsvatnet and Storåna; Hestehaven; Glomma (Figure I) Asellidae were collected from three study areas in southern Norway: one in the west, the lake Stokkalandsvatnet and its outlet stream Storåna; one in the south, the small stream Hestehaven and one in the east, the river Glomma.

Stokkalandsvatnet is around $1.5 \mathrm{~km}$ long with maximum depth around $16 \mathrm{~m}$. The lake receives considerable amounts of nutrients and is eutrophic (Molversmyr et al. 2012). Oxygen depletion in hypolimnion occurs periodically (Åge Molversmyr, pers. comm.). It was sampled in September 2012, by bottom trawl, drawn from the littoral into the deepest part of the lakes, with a $250 \mu \mathrm{m}$ mesh net. Several other lakes in the Stavanger area were sampled during the same study (Spikkeland et al. 2013) (Figure 2).

Storåna joins Stokkalandsvatnet to the ocean in the Sandnes region. It is a small stream, $1.5-2 \mathrm{~m}$ wide, running through an urban area with parks, open areas, roads and buildings (Spikkeland et al. 2013). The bottom material was mostly sand, rocks and detritus, the water velocity moderate, and the river was surrounded by macrophytes. It was sampled at four locations in 2013 by kick sampling and sweeping of macrophytes and soft substrates (Spikkeland et al. 2013; 1mm mesh net) (Figure 2).

Hestehaven is a small ( $1-2 \mathrm{~m}$ wide), wooded, low-gradient stream flowing into a lake, Landvikvannet, Grimstad (Figure 3). Landvikvannet is unusual in that it contains both marine and freshwater fish and is the only non-marine lake in Norway to support herring (Clupea harengus L.). Water is fresh to around $2 \mathrm{~m}$ deepth and becomes increasingly salty and deprived of oxygen below that. Three-

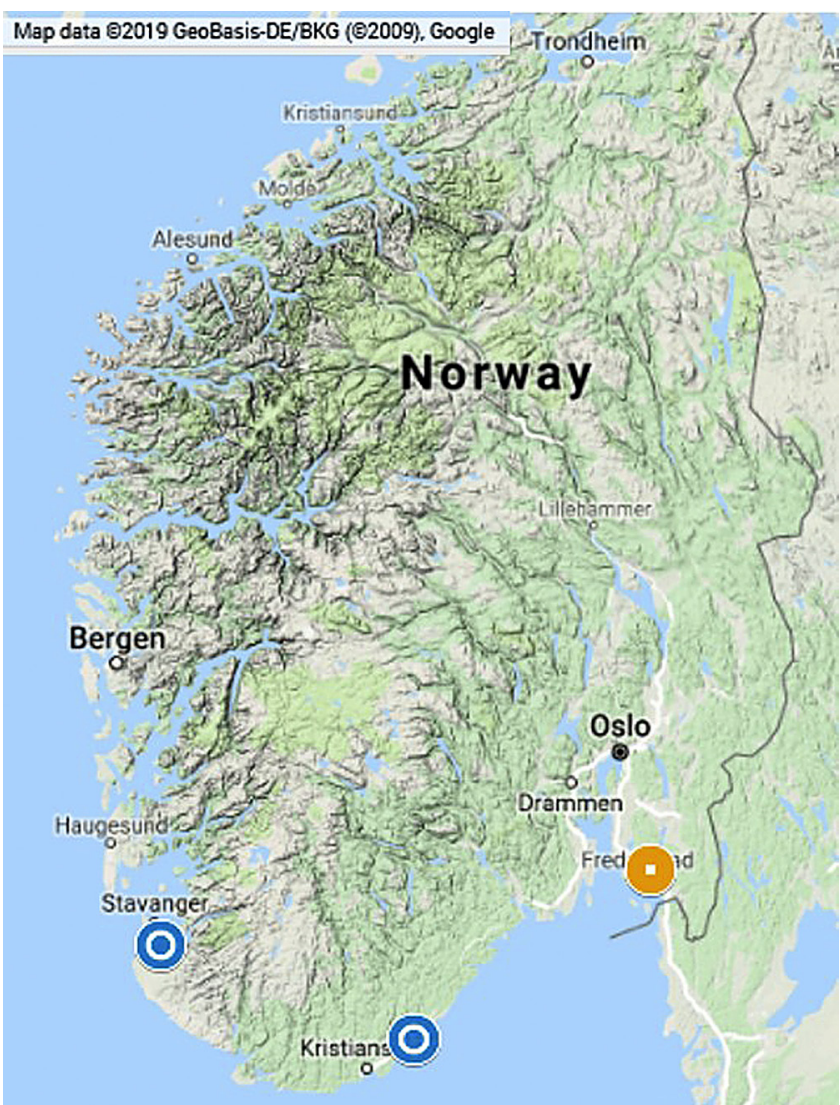

Figure I. Location of Proasellus coxalis (blue circles) and Proasellus meridianus (yellow circle) in Norway. The three areas from west to east: Stokkalandsvatnet \& Lutsivatnet / Hestehaven \& Landvikvannet / Glomma.

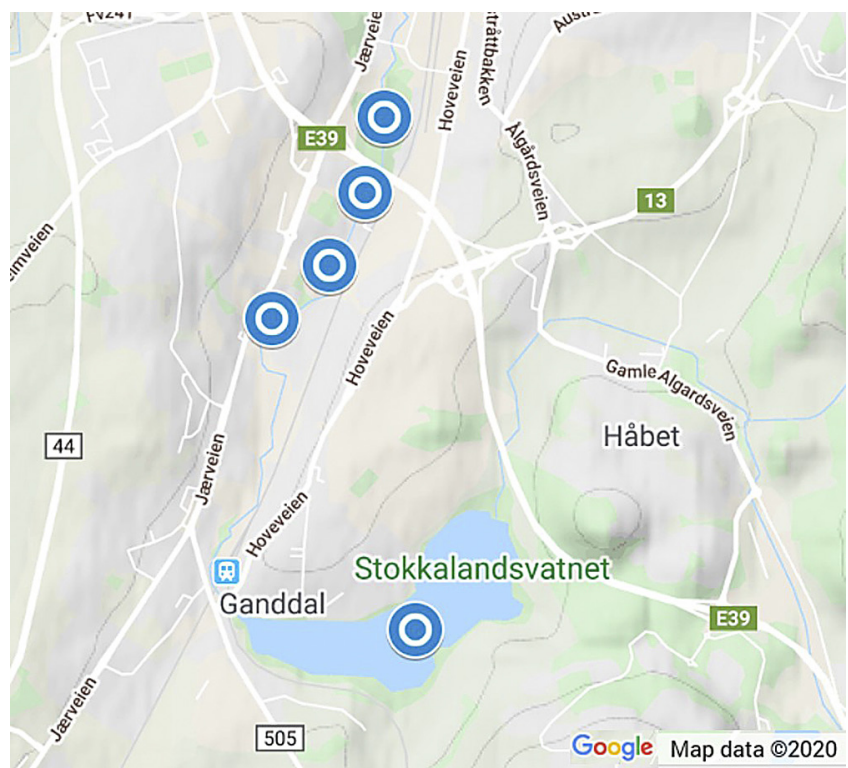

Figure 2. Stokkalandsvatnet and Storåna sites. Blue circle - Proasellus coxalis (from north - south DD 58.841492, 5.7291533; 58.8384417, 5.7277318; 58.8355432, 5.7248868, 58.8333945, 5.7205187; 58.8209635, 5.7316712).

minute kick samples were taken from one site on the Hestehaven stream in May and November 2019, with a $250 \mu \mathrm{m}$ mesh net (Hobæk et al. in press). Several other streams in the area were sampled during the same study

The Glomma is Norway's largest river. The lower Glomma near Sarpsborg has suffered significant levels of industrial organic pollution and monitoring and improvement efforts are ongoing. Most sites were wide, deep and slow flowing, but the upstream sites had faster flow. The native species in Norway, A. aquaticus, had previously been recorded at a number of these sites. Three-minute kick samples were taken in March and December 2018, with a $250 \mu \mathrm{m}$ mesh net, at the sites shown on Figure 4 and listed in Table 1 (Kile et al. 2019ab).

\section{Small investigation into Glomma boat traffic}

Data were obtained from the Marine Traffic website (www. marinetraffic.com) regarding the boats that recorded the small port of Sarpsborg (see Figure 4) as one of their destinations during the (arbitrarily chosen) 13 day period of 23.09.2019 - 05.10.2019. This port is well within the freshwater part of the river. The position of these boats was recorded on arrival/departure from a port and at midnight and noon each day during this time-window.

\section{Morphological identification}

Morphological identification of Asellidae was based on criteria given in Wouters and Vercauteren (2009), Spikkeland et al. (2013) and Gledhill et al. (1993). Specimens are deposited in the collections at Natural History Museum, University of Oslo (ZMO).

\section{Genetic identification: DNA isolation, PCR and sequencing}

Genomic DNA from two Proasellus specimens was isolated using the Qiagen DNeasy Blood and Tissues kit (Qiagen Hilden, Germany) according to the manufacturers protocol. PCR for the cytochrome c oxidase subunit 1 (cox1) gene was performed on a Bio-Rad CFX96 Real-Time PCR Detection System (Bio-Rad Laboratories, Oslo, Norway) using the iProof High-Fidelity PCR Kit (Bio-Rad Laboratories, Oslo, Norway). Amplification of the cox1 
Table 1. Abundances of Asellus aquaticus and Proasellus meridianus in the Glomma, sites arranged in order of year and then upstream to downstream (see also Figure 4).

\begin{tabular}{|c|c|c|c|c|c|c|}
\hline & Latitude (DD) & Longitude (DD) & $\begin{array}{l}\text { Asellus } \\
\text { aquaticus }\end{array}$ & $\begin{array}{l}\text { Proasellus } \\
\text { meridianus }\end{array}$ & $\begin{array}{c}\text { Asellus } \\
\text { aquaticus }\end{array}$ & $\begin{array}{l}\text { Proasellus } \\
\text { meridianus }\end{array}$ \\
\hline & & & & & Oct. 2015 & Oct. 2015 \\
\hline \multirow[t]{2}{*}{ B7 B indre Pæddekummen } & 59,2721835 & 11,0915496 & & & 16 & 7 \\
\hline & & & March 2018 & March 2018 & Dec. 2018 & Dec. 2018 \\
\hline B 1 Sarpsfoss & 59.2798057 & 11.1340354 & 10 & - & - & - \\
\hline B 4 Borregaardsholmen & 59.264923 & 11.1061592 & - & - & 4 & - \\
\hline B 5B Nedre grusørene & 59.2670841 & 11.1011997 & 1 & - & 1 & - \\
\hline B 8 Sundløkka, nedstrøms & 59.2661606 & 11.0839686 & - & - & 1 & - \\
\hline NP 1 Nordic Paper & 59.266095 & 11.0593 & - & - & - & - \\
\hline NP 2 Nordic Paper & 59.265722 & 11.052885 & - & - & - & - \\
\hline NP 3 Nordic Paper & 59.267916 & 11.026556 & 1 & 1 & - & 8 \\
\hline NP 4 Nordic Paper & 59.259329 & 11.02514 & - & - & - & - \\
\hline NP 5 Nordic Paper & 59.249077 & 11.014561 & 1 & 16 & - & 20 \\
\hline
\end{tabular}

gene region was conducted using the newly designed primers PM $77 f$ (cgcyttwatcrgccaycyaac) and PM 1441r (artargtraadacrtcnggrt). The following cycling protocol was used: one cycle of $5 \mathrm{~min}$ at $95{ }^{\circ} \mathrm{C}$, and then 35 cycles each consisting of $50 \mathrm{~s}$ at $95{ }^{\circ} \mathrm{C}, 50 \mathrm{~s}$ at $55{ }^{\circ} \mathrm{C}$, and $1 \mathrm{~s}$ at $72{ }^{\circ} \mathrm{C}$, followed by a final elongation step of 72 ${ }^{\circ} \mathrm{C}$ for $3 \mathrm{~min}$. PCR products were visualized by $1.5 \%$ agarose gel electrophoresis with GelRed staining and UV illumination. For sequencing the same primers and the intermediate primers PM687F (cctcccagtdttagcrggggca), PM655r (cwgaccawacraaaagtggga), PMintlf (ggccatctaacttacccaacga), PMint2f (gccagttcaatcttagggtcag), PMint3f (attattgcagtgccaactggt), PMint4r (ggtatccctccaaccctaag) and PMint5r (acttcaggatggccaaaaaatc) were used. Sequences were analysed and aligned using Seqassem (version 04/2008) and Align (version 03/2007) MS Windows-based manual sequence alignment editor (SequentiX DigitalDNA Processing, Klein Raden Germany) to obtain DNA sequence alignments, which were then corrected manually. For each PCR product, both strands were sequenced on an ABI 3730 Avant genetic analyser using the BigDye terminator V.3.1 cycle sequencing kit (Applied Biosystems, (Applied Biosystems, Thermo Fisher Scientific Oslo, Norway) according to the manufacturer's instructions.

The sequence data were deposited in the European Nucleotide Archive (ENA) under the accession numbers given in Table 2.

\section{Phylogenetic analysis}

Segments with highly variable and ambiguous regions and gaps, making proper alignment impossible, were excluded from the analyses. In addition to two Proasellus samples collected from the river Glomma site "NP 5 Nordic Paper" (Table 1) in December in 2018, a cox1 set containing 63 other Proasellus sequences, and 531 nucleotide positions were used for phylogenetic analysis. A. aquaticus (GU130252) was used as an outgroup taxon in the cox1 tree. The dataset was analyzed using the maximum likelihood (ML) algorithm in MEGA version 7 (Kumar et al. 2016). The method selected T92+G as the best-fitting evolutionary model for the cox1 gene region. ML analyses were performed with 1000 bootstrap replicates in MEGA version 7 (Kumar et al. 2016).

\section{RESULTS}

\section{Stokkalandsvatnet and Storåna}

Specimens of Asellidae were found in all investigated lakes, $P$. coxalis was only recorded from Lake Stokkalandsvatnet, whereas $A$. aquaticus inhabited all lakes. During the further studies in the river Storåna, the outlet of Stokkalandsvatnet, $P$. coxalis was common in all investigated sites.

\section{Hestehaven}

On $03.05 .2019,48$ individuals of $P$. coxalis (including many females with eggs) were found in the Hestehaven kick sample and 480 individuals were found in the sample taken on 24.11.2019. A number of other streams in the surrounding area were sampled as part of the same project and no native or introduced Asellidae species were found in any of the other samples (Hobæk et al. in press). Figure 3 shows the location of the Hestehaven site and the nearby sites where no Asellidae were found.

\section{Glomma}

Nine sites were sampled in spring and winter of 2018 on the river Glomma and $P$. meridianus was found at two of them. In the spring $A$. aquaticus was also found at both of these sites. Only A. aquaticus was found at the more upstream (faster-flowing) sites (Table 1, Kile et al. 2019ab). A number of sites in the same area had also been sampled in 2015 and one of these (site 7B, which had the highest abundances of

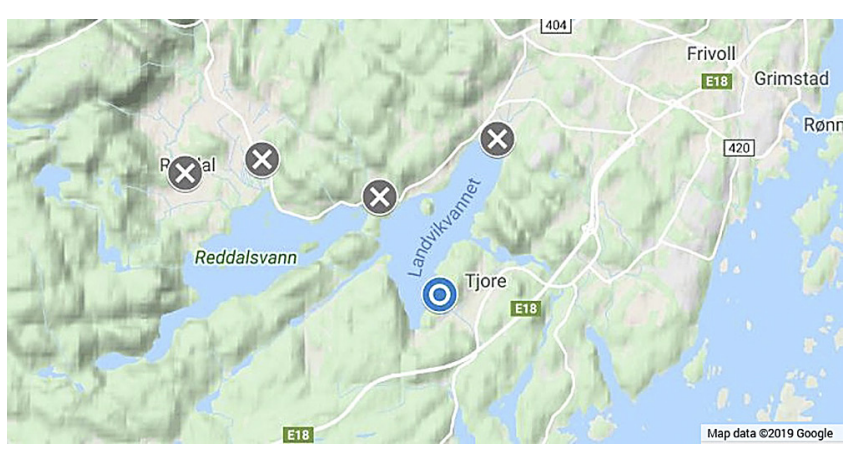

Figure 3. Sites near Landvikvannet. Blue circle - Proasellus coxalis (Hestehaven DD 58.31732 8.50894). Grey cross no Asellidae found. 


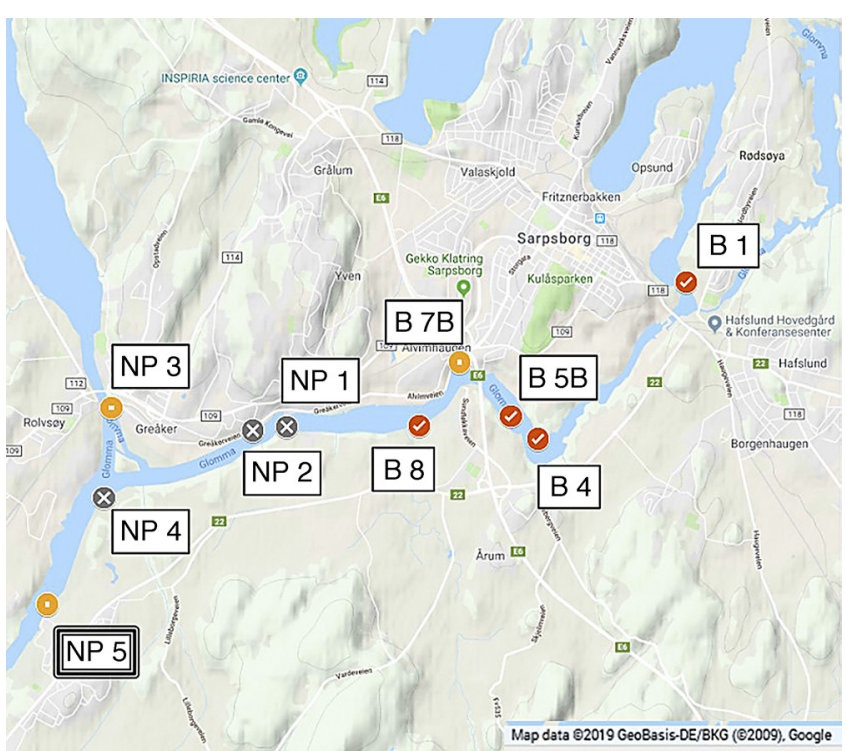

Figure 4. Sites on river Glomma at Sarpsborg. Red circles - Asellus aquaticus. Yellow circles - both A. aquaticus and Proasellus meridianus found. Grey cross no Asellidae found. Site codes correspond to table 1. The two specimens analysed for DNA fingerprinting came from the downstream site NP5. See table 1 for grid references.

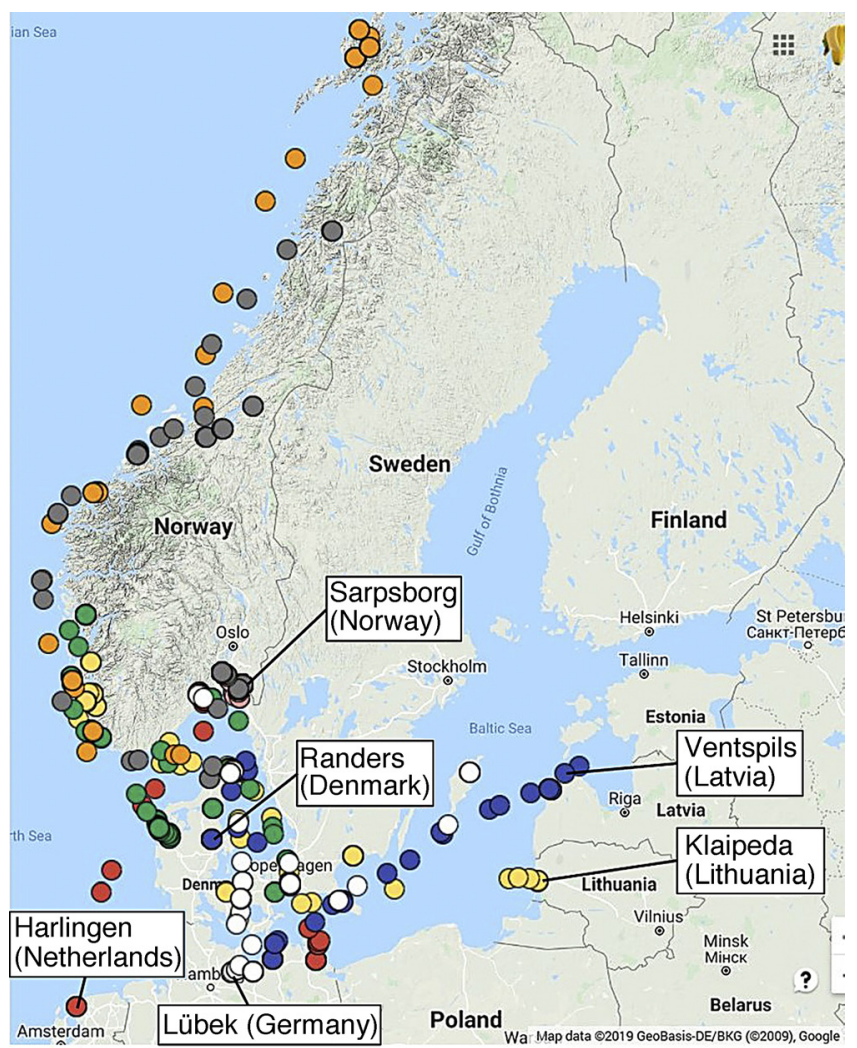

Figure 5. Position of boats that recorded Sarpsborg as a destination between 23.09.2019-05.10.2019. Each boat represented by a different colour.

Table 2. DNA barcoding. sequence data deposited in the European Nucleotide Archive (ENA)

\begin{tabular}{ll}
\hline Species and field ID & ENA accession nr. \\
\hline Proasellus meridianus Glomma 1 & LR736791 \\
Proasellus meridianus Glomma 2 & LR736792 \\
\hline
\end{tabular}

Asellidae in 2015) was re-examined to look for $P$. meridianus (Table 1). Therefore, we know that $P$. meridianus was established in the river in 2015 but was overlooked at that time.

\section{Investigation into Glomma boat traffic.}

During the 13-day period of 23.09.2019 - 05.10.2019, nine boats recorded Sarpsborg among their destinations. One of these stayed within the confines of the Glomma river and estuary, another remained around the Oslo fjord, but the other seven ranged widely, including visiting other European fresh and brackish water ports (Figure 5).

Two boats visited ports where it is possible that $P$. coxalis and/ or $P$. meridianus are present, Lübek in Germany (freshwater) and Harlingen in the Netherlands (brackish with probable freshwater areas/times).

Boats also visited freshwater ports further east in the Baltic, where only A. aquaticus is thought to be present, Klaipeda in the Curonian lagoon, Lithuania and Ventspils in Latvia. The boat that went to Ventspils went about $4 \mathrm{~km}$ up the Venta river and also later visited the freshwater port of Randers on the river Gudenå in Denmark.

Numerous brackish water ports on Norwegian fjords were also visited (e.g. Etnefjord, Porsgrunn) along with others in Denmark (Odense) and Germany (Vierow, Herre). Brackish water is of lower risk for the transport of exclusively freshwater species such as $P$. meridianus, but $P$. coxalis is known to tolerate brackish water. (Note that salinity information was not readily available for many ports so in some cases their freshwater or brackish status has been estimated, based on aerial photographs and other information.)

\section{Barcoding of Proasellus meridianus}

The sequencing analysis of both Norwegian Proasellus specimens confirmed their assignment to the species $P$. meridianus, as both coxl sequences obtained grouped together with other $P$. meridianus sequences in a pure $P$. meridianus cluster, which was supported by a bootstrap value of $100 \%$ (Figure 6a). P. meridianus Glomma 1 was most closely related to $P$. meridianus specimens from France. $P$. meridianus Glomma 2 was grouped in a subcluster together with $P$. meridianus specimens from France, U.K. and Netherlands (Figure 6b).

\section{DISCUSSION}

\section{Ecology and co-existence of the three species}

The three species of Asellidae, A. aquaticus, $P$. coxalis and $P$. meridianus, have similar ecological niches and are known to co-occur pairwise in many localities (e.g. Holthuis 1956, Fano 1974, Moon 1957, 1968). The co-occurrence of these taxonomically closely allied species may seem to challenge the Gause's principle or the principle of competitive exclusion (Hardin 1960). The competitive relationship between $A$. aquaticus and $P$. coxalis appears to be complex and to change according to locality and environmental conditions.

Fano (1974) reported the two species A. aquaticus and $P$. coxalis could be found co-occurring in nature, although they are normally found allopatrically (in separate locations). An experimental laboratory set-up was performed to study competition between the two species, and $P$. coxalis regularly displaced $A$. aquaticus. Fano (1974) added that in polluted waters the species $P$. coxalis probably had a greater adaptive capacity than $A$. aquaticus. Costantini \& Rossi (1998) also found $P$. coxalis to be ecologically dominant under laboratory conditions. 
a)

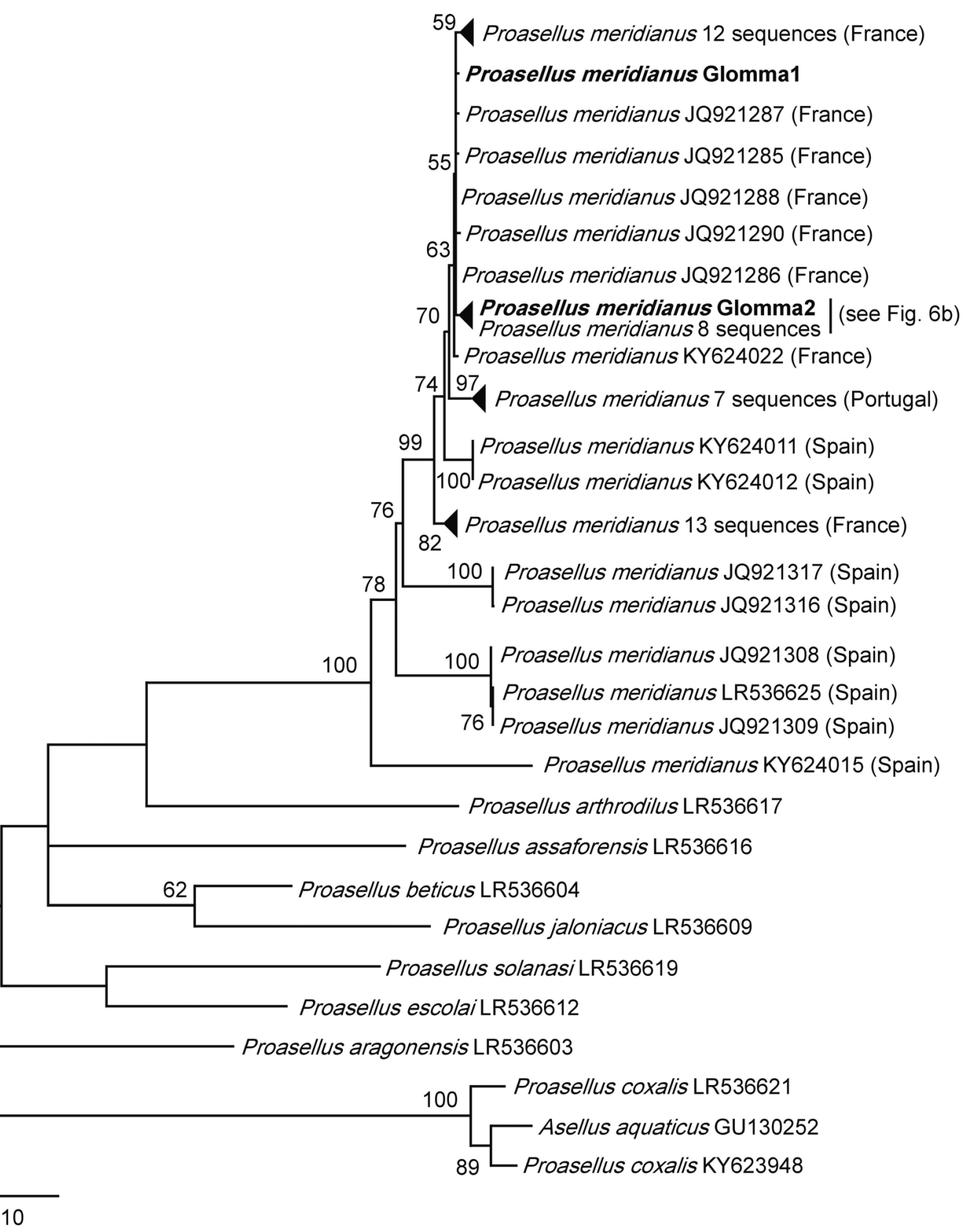

b)

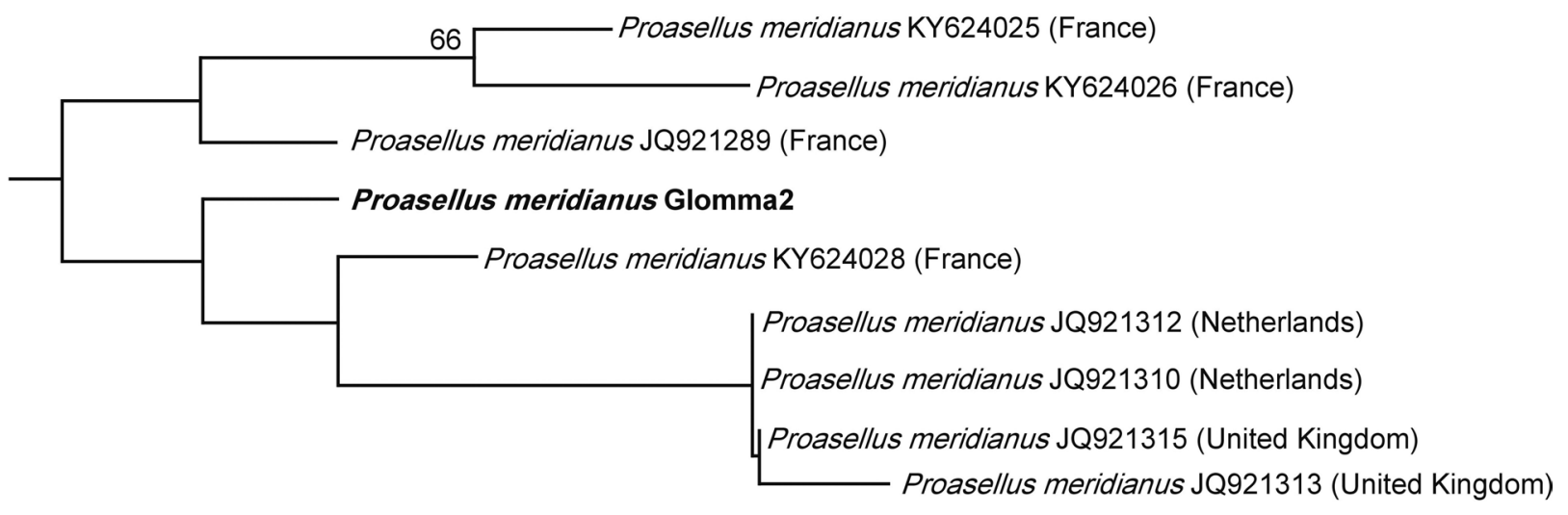

0.002

Figure 6. Maximum Likelihood tree of the coxl gene of Proasellus spp. Bootstrap values above 50 are included. a) phylogenetic tree including 65 Proasellus cox1 sequences. Scale bar indicates $10 \%$ sequence divergence, b) subcluster including 9 Proasellus meridianus cox1 sequences. Scalebar indicates $0.2 \%$. Specimens investigated in this study are marked in bold. 
In nature, Sket (2011) reported that $P$. coxalis outperformed $A$. aquaticus on the Adriatic coast, but this pattern has not been generally seen across northern Europe. Burmeister (2003) observed in Germany that $A$. aquaticus could displace both $P$. coxalis and $P$. meridianus. Henry \& Magniez (1983) observe that $A$. aquaticus, coming from the north, has been displacing $P$. coxalis in the lower Rhone and Camargue.

In a German study, Flössner (1987) found that the two species differed in their timing and size at reproduction. The reproduction of both species was mainly between spring to autumn. Proasellus meridianus started reproducing at a lower size class than A. aquaticus, but $A$. aquaticus was more fecund than $P$. coxalis at higher sizes. At higher autumn temperatures the proportion of $P$. coxalis females that were reproducing was higher than when autumn temperatures were low. This is unsurprising, given that $P$. coxalis is originally a southern species. The author concluded that neither had a clear competitive advantage. In Sweden, $P$. coxalis has not greatly increased its range since its arrival (Cecilia Holmström, pers. comm.). Similarly, several studies have searched for ecological differences between A. aquaticus and $P$. meridianus, but the relationships are not completely resolved.

According to Holthuis (1956) and Grüner (1965), P. meridianus occupies the same habitat as A. aquaticus; in many cases the two species are found together. The life cycles of both species appear nearly identical, apart from minor differences in seasonal timing (Williams 1960, Steel 1961). The same was true for their reproductive capacity (Williams 1960). He also confirmed, both experimentally and in the field, that the two species do not interbreed (Williams 1962a). Williams $(1960,1962 b)$ found no important differences between the two taxa regarding food, micro-habitat, vertical distribution, tolerance for low oxygen concentrations, for high temperatures, or for desiccation. Williams $(1960,1963)$ also investigated the possibility of competition between these species and concluded that $A$. aquaticus and $P$. meridianus compete and that the latter species is gradually being replaced by the former, especially under more eutrophic conditions. In France, A. aquaticus is seen as a relatively recent arrival and spreading thanks to canals. It is described as driving back the endemic P. meridianus in the west (Henry \& Magniez 1983).

In the Netherlands, the population ecology of the two taxa was studied in a reed bed in Tjeukemeer from March to October. Densities of the two species were similar at the start and at the end of the reproductive season, whereas $P$. meridianus was up to 3 times more abundant in between. Egg production in both species was positively correlated to body length, and summer brood sizes were smaller than those in spring. P. meridianus began reproduction at smaller bodysizes than A. aquaticus and was also the more fecund for comparable size classes. Over the season as a whole, both species had similar reproductive output. The life cycle of the two species was similar, with three main periods of reproduction and the populations being replaced twice during the year. Despite the minor differences between the species, no single factor was identified which would give one species an obvious competitive advantage over the other Chambers (1977).

Overall, A. aquaticus is thought to have a greater tolerance to organic pollution, higher salinities, low $\mathrm{pH}$ and high metal concentrations than P. meridianus (Gledhill et al. 1993).

\section{Dispersal}

The three species of Asellidae, A. aquaticus, $P$. coxalis and $P$. meridianus, have different zoogeographical origins, but increasingly overlapping ranges.

Dispersal of freshwater invertebrates is affected by many factors and vectors. Recently, human activities have played a very important role as vectors in their dispersal. In continental Europe, one of the major factors has been the construction of shipping canals, which disrupt natural barriers between catchments. Of particular significance to the Asellidae has been the "western invasion corridor" of the Rhine-Rhone canal. Opened in 1833, this created a direct freshwater connection between the Mediterranean and the North Sea. It is thought to have aided the spread of both $P$. coxalis and $P$. meridianus to the Rhine and neighbouring basins (Galil et al. 2007).

Inadvertent species introductions by fishermen are strongly suspected for introducing a number of species, including $P$. coxalis, in the south eastern Jæren area of Norway. Fishermen from Germany may have introduced rudd (Scardinius erythrophthalmus), used as live bait and carried over in microaquaria, into Storelva (Arnold \& Längert 1995). Small rudd were probably used as live bait for eels, with the water and bottom material from the microaquaria also emptied into the lake or river. This would also explain the appearance of their parasite, Argulus foliaceus (common fish louse), not previously been found in the Jæren area. Haitia (Physa) acuta may have been introduced the same way, or by local people emptying home aquaria, as it is commonly found on aquarium plants (Spikkeland et al. 2013). The microaquaria could also be responsible for arrivals in other areas, such as Daphnia ambigua (originally American) in the Arendal area (Nilssen 2009 a).

This is the first record of $P$. meridianus for the Nordic countries, including Denmark (Danmarks Miljøportal 2019), despite it being common in Germany. The dispersal mechanism of P. meridianus to Norway is, of course, not certain, but ballast water or other water use by ships must be strongly suspected. In addition to ballast water, freshwater can be taken into or discharged from a ship for other purposes, such as maintenance or engine cooling. Since the nearest records of this species are in Germany, it has probably not reached the delta of the Norwegian river Glomma without the help of human vectors. The idea of the small study into shipping is a demonstration of principle, rather than to point the finger or to pinpoint exactly where the animals have arrived from.

Ships from Europe visit ports in the area frequently, as far upstream as the Borregaard industrial complex, which is adjacent to the sites where $P$. meridianus have been found and well within the freshwater part of the river. Some of these ships visit European ports with brackish and freshwater areas (Figure 5) and sail extensively on the European freshwater canal network. Transport via the boats' surface-fouling ("aufwuchs") is highly unlikely, due to the sensitivity of $P$. meridianus to saltwater. An investigation from the Netherlands demonstrated that $P$. meridianus was only found in oligo-haline waters (with a salinity from $28-1700 \mathrm{mg} / \mathrm{L} \mathrm{Cl}$ ), whereas both $A$. aquaticus and $P$. coxalis could tolerate salinities up to $3300 \mathrm{mg} / \mathrm{L} \mathrm{Cl}$ (Boets. et al. 2011), which is close to meso-haline waters.

Grigorovich et al. (2003) used shipping patterns, ballast water practices and species characteristics to identify species that are at risk of arriving in the American Great Lakes. They concluded that both $P$. coxalis and $P$. meridianus could both potentially be introduced from Europe.

Natural long-range dispersal by birds from mainland Europe to Norway is improbable, although theoretically possible (Figuerola \& Green 2002).

\section{Are they invasive?}

Non-indigenous species can induce major changes to the recipient environment, such as altering and disrupting the biotic structure of ecosystems, affecting the ecology of other species to the extent of driving many species towards local extinction. "Invasive" is usually 
reserved for species which establish themselves very rapidly, displace original species and have ecosystem-level effects.

Sandvik et al. (2019) recently published criteria for assessing the impact of alien species, as well as an updated assessment of 1,183 alien species currently reproducing in mainland Norway (Sandvik et al. 2020a,b). They used a risk assessment matrix. Proasellus coxalis was given an overall rating of "no known impact", based on its invasiveness potential (defined in terms of population lifetime, expansion speed and $\%$ colonisation of ecosystems) and ecological effect (effects on threatened or keystone species, effects on other native species, effects on rare or threatened ecosystems, effects on other ecosystems, genetic contamination and transmission of parasites). They felt that climate change would help this species in Norway.

Experience from other countries (but not yet Sweden) shows that the invasion potential of $P$. coxalis, could be rather high, when judged over the long term. It has established new, healthy populations in Norway at least twice, with some expansion in the eastern population. The overall risk assessment, however, would still be "no known impact", if we judge the likely ecological effect to be negligible. For Sandvik et al. (2019) ecological effect is partly based on the extent to which the new species is likely to displace native species. This is difficult to judge, as when the species of Asellidae have met previously, there has been no clear pattern of one dominating the others. They are unlikely to significantly change ecosystem processes, however, due to their ecological similarity.

Other studies have not considered P. coxalis and P. meridianus to be true invasive species, since they seem to have a small effect on other species and the total ecosystem (Wittfoth \& Zettler 2013). In a recent study of risk factors of non-indigenous species in rivers and canals in Germany, both $P$. coxalis and P. meridianus were added to the "Grey List" and not the "Black List" (Panov et al. 2009). Josens et al. (2005) describe them as exotic, but not invasive, in the Netherlands.

Their ability to spread, establish themselves and negatively influence the ecological and socio-economical functioning of the recipient environment is not known according to Panov et al. (2009). Dobson (2013) did not mention P. coxalis in his guide covering invading and potentially invading freshwater organisms on the British Isles. Ironically, in Sweden, $P$. coxalis was listed as a strongly threatened species (EN) in ArtDatabanken (2015), elucidating the great paradox that newly migrated, unwanted species can be considered threatened while in an early phase of spreading and establishing themselves in the novel region (Nilssen 2009b).

\section{Competition and future spread}

In some previous scenarios where $A$. aquaticus and $P$. meridianus have met, authors have thought that $A$. aquaticus had displaced $P$. meridianus, such as in the U.K. Williams (1962c, 1963) also thought that the eastward distribution of $P$. meridianus in Europe was checked when it met with $A$. aquaticus colonising westwards, from its Pleistocene ice refuge, and that $A$. aquaticus would continue to spread and replace $P$. meridianus.

The situation in Norway is the opposite, with P. meridianus arriving into well-established $A$. aquaticus populations. This arrival of $P$. meridianus into A. aquaticus populations has already been observed in a number of continental European countries. It will be interesting to see if $P$. meridianus spreads out from its new home and if it will have any effects on populations of A. aquaticus. As $A$. aquaticus is thought to be more tolerant of organic pollution, higher salinities, low $\mathrm{pH}$ and high metal concentrations than P. meridianus (Gledhill et al. 1993), A. aquaticus should retain the upper hand in certain situations.
The new arrival in the south west and south of Norway and Sweden, $P$. coxalis, has been reported to displace A. aquaticus in some cases but not in others (Fano 1974, Burmeister 2003). The fact that it has spread gradually northwards in Europe and established a number of healthy populations in Norway and Sweden suggests that the species can continue to spread. It now inhabits both lakes and running waters in Norway.

Watching the introduced populations of these species in Norway and Sweden may help to further understand their ecological differences. The relative competitive advantages of the different species may well vary over time and location, related to pollution levels, acidity and climate change.

These Proasellus species have now successfully established populations in Norway on at least 3 occasions, showing that current practices are ineffective at stopping freshwater species arriving from overseas. Looking at the shipping pattern from just one small port in Norway it is easy to see the potential for further spread both internationally and around Norway.

The potential for ballast water to transfer strictly freshwater species internationally may not have been fully realised by policy makers. The number and connectivity of freshwater ports around northern Europe is surprisingly high.

The subtleties of salinity, habitat and water current barriers to species dispersal have not been appreciated by all of the shipping sector. Van der Meer et al. (2016) reported that $67 \%$ of shipping companies thought that there was no need to perform Ballast Water Management in the North Sea and 92\% thought there should be exemptions from regulations, as they erroneously saw it as an ecologically homogeneous area.

It is inevitable that these and other, potentially harmful, species will continue to spread fairly frequently across what should be natural barriers, if current patterns of human behavior persist.

This paper provides, for the first time, a detailed photo guide to these three species (Appendix 1). By making this widely available, it will increase the knowledge and accuracy of information about them.

\section{ACKNOWLEDGEMENTS}

Thierry Vercauteren provided identification verification and a great deal of help and support. Thierry Vercauteren, an anonymous reviewer and Torkild Bakken gave comments that substantially improved the manuscript. Cecilia Holmström, Ekologigrupen, provided Swedish $P$. coxalis information and specimens. Eivind Ekholt Andersen, NIVA, found $P$. coxalis in Hestehagen and Johnny Håll, NIVA, provided data. Ship location information was supported by MarineTraffic (www. marinetraffic.com). Borregaard and Nordic Paper funded the river Glomma project. Vest-Agder fylkeskommune funded the project that included the Hestehagen site. We would like to heartily thank them all!

\section{REFERENCES}

Arnold A, Längert H. 1995. Das Moderlieschen Leucaspius delineatus: Biologie, Haltung und Artenschutz. Die Neue Brehm-Bücherei, Westarp Wissenschaften, Magdeburg, Spektrum Akademischer Verlag, Heidelberg, Berlin, Oxford: $121 \mathrm{p}$.

ArtDatabanken 2015. Rödlistade arter i Sverige 2015. ArtDatabanken SLU, Uppsala. 209 pp.

Artsdatabanken. www.artsdatabanken.no Accessed 2019-06-14.

Boets P, Lock K, PLM Goethals PLM. 2011. Shifts in the gammarid 
(Amphipoda) fauna of brackish polder waters in Flanders (Belgium). Journal of Crustacean Biology 31(2): 270-277. doi: 10.1651/10-3357.1

Burmeister, E-G. 2003. Rote Liste gefährdeter wasserbewohnender Krebse, exkl. Kleinstkrebse (limn. Crustacea) Bayerns.

Buschbaum C, Lackschewitz D. Reise K. 2012. Nonnative macrobenthos in the Wadden Sea ecosystem. Ocean \& Coastal Management 68: 89-101. doi: 10.1016/j.ocecoaman.2011.12.011

Chambers MR. 1977. A comparison of the population ecology of Asellus aquaticus (L.) and Asellus meridianus Rac. in the reed beds of the Tjeukemeer. Hydrobiologia 53(2): 147-154. doi: 10.1007/BF00029293

Costantini ML, Rossi L. 1998. Competition between two aquatic detritivorous isopods - a laboratory study. Hydrobiologia 368 (1-3): 17-27. doi: 10.1023/A:1003296620693

Danmarks Miljøportal. http://naturdata.miljoeportal.dk/ Accessed 201906-14.

Davis MA, Hobbs RJ, Lugo AE, Ewel JJ, Vermeij GJ, Brown JH, Rosenzweig ML, Gardener MR, Carroll SP, Thompson K, Pickett STA, Stromberg JC, Del Tredici P, Suding KN, Ehrenfeld JG, Grime JP, Mascaro J, Briggs JC. 2011. Don't judge species on their origins. Nature. 474: 153-154. doi: 10.1038/474153a

de Vaate AB, Jazdzewski K, Ketelaars HAM, Gollasch S, van der Velde G. 2002. Geographical patterns in range extension of Ponto-Caspian macroinvertebrate species in Europe. Canadian Journal of Fisheries and Aquatic Sciences 59: 1159-1174.

Dobson M. 2013. Identifying invasive freshwater shrimps and isopods, Revised edn. Freshwater Biological Association, Ambleside

Fano EA. 1974. Ricerche sui rapporti fra due specie del genere Asellus. Nota I. Competizione. Atti della Accademia Nazionale dei Lincei. Classe di Scienze Fisiche, Matematiche e Naturali. Rendiconti 56 (6) 976-983.

Figuerola J, Green AJ. 2002. Dispersal of aquatic organisms by waterbirds: a review of past research and priorities for future studies. Freshwater Biology 47: 483-494. doi: 10.1046/j.1365-2427.2002.00829.x

Flasarová M. 1975. Proasellus coxalis septentrionalis (Herbst) (Isopoda: Asellota) in Böhmen und Mähren. Věstník Československé společnosti zoologické. 39: 254-264.

Flasarová M. 1996. Poznámky o Isopodech (Crustacea: Isopoda: Asellota and Oniscidea) v severozápadních Čechách. I. Sborník Okresního muzea v Mostě, řada př́rodovědná 18: 18-20.

Flössner D. 1987. Populationsdynamik and Produktion von Asellus aquaticus (L.) und Proasellus coxalis (Dollfus) in der mittleren Saale. Limnologica 18: 279-295.

Galil BS, Nehring S, Panov V. 2007. 5 Waterways as invasion highways - impact of climate change and globalization. In: Nentwing W. (ed). Biological invasions. Ecological studies 193. Berlin: Springer - Verlag pp. $64-74$.

Gledhill T, Sutcliffe DW, Williams WD. 1993. British Freshwater Crustacea Malacostraca: a key with ecological notes. Freshwater Biological Association $173 \mathrm{p}$.

Gollasch, S. \& Nehring, S. 2006. National checklist for aquatic alien species in Germany. Aquatic Invasions 1 (4): 245-269. doi: 10.3391/ ai.2006.1.4.8

Gregory S. 2009. Woodlice and Waterlice (Isopoda: Oniscidea \& Asellota) in Britain and Ireland. NERC Biological Records Centre. 175 p.

Grigorovich IA, Colautti RI, Mills EL, Holeck K, Ballert AG, Maclsaac J. 2003. Ballast-mediated animal introductions in the Laurentian Great Lakes: retrospective and prospective analyses. Canadian Journal of Fisheries and Aquatic Sciences. 60 (6): 740-756. doi: 10.1139/f03-053

Grüner H-E. 1965. Krebstiere oder Crustacea. V. Isopoda. In: Dahl F (eds). Die Tierwelt Deutschlands und der angrenzenden Meeresteile nach ihren Merkmalen und nach ihrer Lebensweise, Teil 51 und 53. Verlag G. Fischer, Jena. 380 p.

Hardin G. 1960. The Competitive Exclusion Principle. Science. 131:12921297.

Henry J-P, Magniez G. 1983. Introduction pratique à la systématique des organismes des eaux continentales françaises - 4 . Crustacés Isopodes (principalement Asellotes). Bulletin mensuel de la Société Linnéenne de Lyon. 52: 319-357. doi: 10.3406/linly.1983.10613

Herhaus KF. 1977. Die Verbreitung von Proasellus coxalis (Dollfus, 1892) (Crustacea, Isopoda, Asellidae) in Mitteleuropa. Zoologischer Anzeiger Jena 199: 314-324.

Heuss K. 1976. Neufunde von Proasellus coxalis (Dollfus, 1892) (Crustacea, Isopoda, Asellidae) in Deutschland und der Schweiz. Gewässer und Abwässer 60/61: 70.

Hewitt GM. 1999. Post-glacial recolonization of European biota. Biological Journal of The Linnean Society 68: 87-112. doi: 10.1111/ j.1095-8312.1999.tb01160.x

Hidding B, Michel E, Natyaganova AV, Sherbakov DY. 2003. Molecular evidence reveals a polyphyletic origin and chromosomal speciation of Lake Baikal's endemic asellid isopods. Molecular Ecology 12: 1509-1514. doi: 10.1046/j.1365-294x.2003.01821.x

Hobæk A, Håll J, Skjelbred B, Håvardstun J. In press. Problemkartlegging av eutrofierte vannforekomster I vannområdene Gjerstad-Vegår, Nidelva og Tovdalselva. Resultater fra overvåking 2018-2019. NIVA Rapport. 84 p.

Holthuis LB, 1956. Notities betreffende limburgse Crustacea III. De Amphipoda (Vlokreeftjes) van Limburg. Natuurhistorisch Maandblad $45(7-8)$.

Huwae and Rappé. 2003. Waterpissebedden. Een determineertabel voor de zoet-, brak- en zoutwaterpissebedden van Nederland en Belgie.KNNV Wetenschappelijke Mededeling (KNNV Uitgeverij) Utrecht 226, $55 \mathrm{p}$.

IPBES 2018. Summary for policymakers of the regional assessment report on biodiversity and ecosystem services for Europe and Central Asia of the Intergovernmental Science-Policy Platform on Biodiversity and Ecosystem Services. M. Fischer, M. Rounsevell, A. Torre-Marin Rando, A. Mader, A. Church, M. Elbakidze, V. Elias, T. Hahn. P.A. Harrison, J. Hauck, B. Martín-López, I. Ring, C. Sandström, I. Sousa Pinto, P. Visconti, N.E. Zimmermann and M. Christie (eds.). IPBES secretariat, Bonn, Germany. 38 p. doi: 10.1126/science.aap8826

Josens G, Bij de Vaate, Usseglio-Polatera P, Cammaerts R, Che'rot F, Grisez F, Verboonen P \& Vanden Bossche J-P. 2005. Native and exotic Amphipoda and other Peracarida in the River Meuse: new assemblages emerge from a fast changing fauna. Hydrobiologia 542: 203-220. doi: 10.1007/s10750-004-8930-9

Ketmaier V, Argano R, Cobolli M, De Matthaeis E, Messana G. 2001. A systematic and biogeographical study of epi- and hypogean populations of the Proasellus species group from Sardinia, central Italy and Jordan: Allozyme insights. Journal of zoological systematics and evolutionary research 39: 53-61. doi: 10.1046/j.1439-0469.2001.00154.x

Ketmaier V. 2002. Isolation by distance, gene flow and phylogeography in the Proasellus coxalis-group (Crustacea, Isopoda) in Central Italy: allozyme data. Aquatic sciences 64: 66-75. doi: 10.1007/s00027-002$8055-\mathrm{Z}$

Kile MR, Kemp JL, Andersen EE, Lund E, Ranneklev SB, Thaulow J. 2019 Tiltaksrettet overvåking av Glomma ved Borregaard 2018a. NIVA Rapport; 7354. 48 p. http://hdl.handle.net/11250/2587950

Kile MR, Kemp JL, Ranneklev SB, Andersen EE. 2019b. Tiltaksrettet overvåking av potensielle effekter av utslipp fra Nordic Paper AS på $ø$ kologisk og kjemisk tilstand i nedre del av Glomma i 2018. NIVA Rapport; 7339. 49 p. http://hdl.handle.net/11250/2587136

Knoben RAE, Peeters ETHM. 1997. Eco-atlas van waterorganismen. Deel IV: zoöplankton en macrofauna (exclusief insecten). Stowa. 195 p.

Kumar S, Stecher G, Tamura K. 2016. MEGA7: Molecular Evolutionary Genetics Analysis Version 7.0 for Bigger Datasets. Molecular Biology and Evolution. 33(7): 1870-1874. doi: 10.1093/molbev/msw054

Messiaen M, Lock K, Gabriels W, Vercauteren T, Wouters Karel, Boets P, Goethals P. 2010. Alien macrocrustaceans in freshwater ecosystems in the eastern part of Flanders (Belgium). Belgian Journal of Zoology. 140: 30-39. http://hdl.handle.net/1854/LU-971089

Molversmyr Å, Schneider S, Bergan MA, Edvardsen H, Mjelde M. 2012. Overvåkning av Jærvassdrag 2011. Datarapport. International 
Research Institute of Stavanger. Rapport IRIS - 2012/023.

Moon HP. 1957. The distribution of Asellus in the English Lake District and adjoining areas. Journal of Animal Ecology. 26: 403-409. doi: $10.2307 / 1755$

Moon HP. 1968. The colonization of Esthwaite Water and Ullswater, English Lake District, by Asellus (Crustacea, Isopoda). Journal of Animal Ecology. 37: 405-415. doi: 10.2307/2956

Nehring S. 2002a. Different human mediated vectors for non-indigenous macrozoobenthic species. In: Leppäkoski E, Gollasch S, Olenin S (eds). 2002 Invasive Aquatic Species of Europe: Distribution, Impacts and Management. KLUWER Academic Publishers, Dordrecht, The Netherlands. $583 \mathrm{pp}$.

Nehring S. 2002b. Biological invasions into German waters: an evaluation of the importance of different human-mediated vectors for nonindigenous macrozoobenthic species. pp. 373-383. In: Leppakoski E, Olenin S, Gollasch S (eds). Alien species in European waters. Kluwer, Dordrecht.

Nehring S. 2005. International shipping - a risk for aquatic biodiversity in Germany. In Nentwig W, Bacher S, Cock M, Dietz HJ, Gigon A, Wittenberg R. (eds). Biological invasions - From Ecology to Control. Neobiota 6: 125-143.

Nehring S. \& Leuch H. 1999. Neozoa (Makrozoobenthos) an der deutschen Nordseeküste - Eine Übersicht. Bundesanstalt für Gewässerkunde. 132 p.

Nentwig W (2007) Biological Invasions: why it Matters. In: Nentwig W (ed). Biological invasions. Ecological Studies, vol 193. Springer-Verlag Berlin Heidelberg New York. 441 p.

Nilssen JP. 2009a. Områder med høy akvatisk biodiversitet og uvanlige artskombinasjoner i Aust-Agder; med særlig henblikk på mikrokrepsdyr, samt spesielt bevaringsverdige innsjøtyper, dammer og våtmarker (Regions with high aquatic biodiversity and unusual species combinations in [the County of] Aust-Agder; with special reference to microscrustaceans, in addition to special 'bevaringsverdige'/protected lakes, ponds and wetlands). Müller-Sars Society. Report no. 7 - 2009. 44 p. ISBN: 978-82-8030-016-4. [in Norwegian].

Nilssen JP. 2009b. Vedvarende menneskeindusert spredning av bredspektret ferskvannfisk til og internt i Norge: et holarktisk, $ø$ kologisk perspektiv (Continuous human dispersal of broad-niched freshwater fish to and inside Norway: an Holarctic, ecological perspective). Müller-Sars Society. Report no. 10 - 2009. 78 pp. ISBN: 978-82-8030-003-4. [in Norwegian, Abstract in English].

Økland KA. 1978. Life history and growth of Asellus aquaticus (L.) in relation to environment in a eutrophic lake in Norway. Hydrobiologia 59(3): 243-259.

Panov VE, Alexandrov B, Arbaciauskas K, Binimelis R, Copp GH, Grabowski M, Lucy F, Leuven RS, Nehring S, Paunovic M, Semenchenko V, Son MO. 2009. Assessing the Risks of Aquatic Species Invasions via European Inland Waterways: From Concepts to Environmental Indicators. Integrated Environmental Assessment and Management 5(1): 110-126. doi: 10.1897/ieam 2008-034.1

Post D, Landmann M. 1994. Verbreitungsatlas der Fließgewässerfauna in Ostfriesland. Staatliches Amt für Wasser und Abfall, Aurich 141 p.

Sandvik H, Hilmo O, Finstad AG, Hegre H, Moen TL, Rafoss T, Skarpaas O, Elven R, Sandmark H, Gederaas L. 2019. Generic ecological impact assessment of alien species (GEIAA): the third generation of assessments in Norway. Biological Invasions 21: 2803-2810. doi: 10.1007/s10530-019-02033-6

Sandvik H, Hilmo O, Henriksen S, Elven R, Åsen PA, Hegre H, Pedersen O, Pedersen PA, Solstad H, Vandvik V, Westergaard KB, Ødegaard F, Åström S, Elven H, Endrestøl A, Gammelmo Ø, Hatteland BA, Solheim H, Nordén B, Sundheim L, Talgø V, Falkenhaug T, Gulliksen B, Jelmert A, Oug E, Sundet J, Forsgren E, Finstad A, Hesthagen T, Nedreaas K, Wienerroither R, Husa V, Fredriksen S, Sjøtun K, Steen H, Hansen H, Hamnes IS, Karlsbakk E, Magnusson C, Ytrehus B, Pedersen HC, Swenson JE, Syvertsen PO, Stokke BG, Gjershaug JO, Dolmen D, Kjærstad G, Johnsen SI, Jensen TC, Hassel K, Gederaas L. 2020a. Alien species in Norway: Results from quantitative ecological impact assessments. Ecological Solutions and Evidence. 1: 1-12. doi: 10.1002/2688-8319.12006

Sandvik H, Hilmo O, Henriksen S, Elven R, Åsen PA, Hegre H, Pedersen O, Pedersen PA, Solstad H, Vandvik V, Westergaard KB, Ødegaard F, Åström S, Elven H, Endrestøl A, Gammelmo Ø, Hatteland BA, Solheim H, Nordén B, Sundheim L, Talgø V, Falkenhaug T, Gulliksen B, Jelmert A, Oug E, Sundet J, Forsgren E, Finstad A, Hesthagen T, Nedreaas K, Wienerroither R, Husa V, Fredriksen S, Sjøtun K, Steen H, Hansen H, Hamnes IS, Karlsbakk E, Magnusson C, Ytrehus B, Pedersen HC, Swenson JE, Syvertsen PO, Stokke BG, Gjershaug JO, Dolmen D, Kjærstad G, Johnsen SI, Jensen TC, Hassel K, Gederaas L. 2020b. Data from: Ecological impact assessments of alien species in Norway, v2, Dryad, D

Schmitt T. Varga Z. 2012. Extra Mediterranean refugia: The rule and not the exception? Frontiers in Zoology 9: 22. doi: 10.1186/1742-9994-9-22

Siegel E. 2019. Ferskvandsbænkebideren Proasellus coxalis (Dollfus, 1892) - ny art for Danmark. https://www.fugleognatur.dk/forum/show_ message.asp?page $=1 \&$ MessageID $=1988436 \&$ ForumID $=4$. Accessed 2019-11-19.

Sket B. 2011. Aquatic Isopods (Crustacea Isopoda) of the wider Dinaric Area. In Zidar P, Strus J. 2011 (eds). Proceedings of the 8th International Symposium of Terrestrial Isopod Biology. University of Ljubljana, Biotechnical faculty, Department of Biology. 159 pp 13-16.

Spikkeland I, Nilssen JP, Kinsten B, Kjellberg G. 2013. En ny ferskvannsisopode Proasellus coxalis (Dollfus, 1892) i Norge menneskeindusert bioinvasjon som følge av grenseoverskridende sports- og mataukefiske? (A new freshwater isopod Proasellus coxalis in Norway - illegal introduction due to transboundary fishing?). Fauna 66: 54-62 [in Norwegian, Summary, Figures and Tables in English].

Steel EA. 1961. Some observations on the life history of Asellus aquaticus (L.) and Asellus meridianus Racovitza (Crustacea: Isopoda). Proceedings of the Zoological Society of London. 137: 71-87. doi: 10.1111/j.1469-7998.1961.tb06162.x

Stoch F, Valentino F, Volpi E. 1996. Taxonomic and biogeographic analysis of the Proasellus coxalis-group (Crustacea, Isopoda, Asellidae) in Sicily, with description of Proasellus montalentii n. sp. Hydrobiologia 317: 247-258. doi: 10.1007/BF00036474

Sworobowicz L, Grabowski M, Mamos T, Burzynski A, Kilikowska A, Sell J, Wysocka A. 2015. Revisiting the phylogeography of Asellus aquaticus in Europe: Insights into cryptic diversity and spatiotemporal diversification. Freshwater Biology 60(9): 1824-1840. doi: 10.1111/ fwb. 12613

Thienemann A. 1950. Verbreitungsgeschichte der Süßwassertierwelt Europas. In Thienemann A. (ed): Die Binnengewässer 18. 809 p (Schweizerbart) Stuttgart.

Tittizer T. 1996. Vorkommen und Ausbreitung aquatischer Neozoen (Makrozoobenthos) in den Bundeswasserstraßen. In: Gebhardt H, Kinzelbach R and Schmidt-Fischer S (eds.) Gebietsfremde Tierarten. Auswirkungen auf einheimische Arten, Lebensgemeinschaften und Biotope. Umweltministerium Baden Württemberg. Ecomed Verlagsgesellschaft, Landsberg. pp 49-86.

Tittizer T, Schöll F, Banning M, Haybach A and Schleuter M. 2000. Aquatische Neozoen im Makrozoobenthos der Binnenwasserstraßen Deutschlands. Lauterbornia 39: 1-72.

Valentino F, Del Marco A, Rocchi A. 1983. Nuclear DNA content of Asellus aquaticus and Proasellus coxalis. Journal of Zoological Systematics and Evolutionary Research. 21: 262-265.

van der Meer R, de Boer MK, Liebich V, ten Hallers C, Veldhuis M, Ree K. 2016. Ballast Water Risk Indication for the North Sea, Coastal Management. 44(6): 547-568. doi: 10.1080/08920753.2016.1233794

van der Velde G, Nagelkerken I, Rajagopal S, Bij de Vaate AB. 2002. Invasions by Alien Species in Inland Freshwater Bodies in Western Europe: The Rhine Delta. In: Leppäkoski E, Gollasch S, Olenin S. (eds). Invasive Aquatic Species of Europe. Distribution, Impacts and Management. Springer, Dordrecht. pp. 360-372. doi: 10.1007/978-94- 
015-9956-6 37

Verovnik R, Sket B, Trontelj P. 2005. The colonization of Europe by the freshwater crustacean Asellus aquaticus (Crustacea: Isopoda) proceeded from ancient refugia and was directed by habitat connectivity. Molecular Ecology 14: 4355-4369. doi: 10.1111/j.1365294X.2005.02745.X

Vitagliano Tadini G, Fano EA, Colangelo M. 1988. The life history evolution of Asellus aquaticus (L.) explains its geographical distribution, SIL Proceedings, 1922-2010, 23:4, 2099-2106. doi: 10.1080/03680770.1987.11899857

Williams, WD. 1960. The ecology of Asellus aquaticus (Linnaeus) 1758 and A. meridianus Racovitza 1919. Thesis Ph.D. degree, Liverpool.

Williams WD. 1962a. Some remarks on phenotypic variation and genetic isolation in Asellus (Isopoda, Asellota). Crustaceana 4: 279-284.

Williams, WD. 1962b - Notes on the ecological similarities of Asellus aquaticus (L.) and A. meridianus Rac. (Crust., Isopoda). Hydrobiologia 20: 1-30. doi: 10.1007/BF00038733

Williams WD. 1962c. The geographical distribution of the isopods Asellus aquaticus (L.) and A. meridianus Rac. Proceedings of the Zoological Society of London 139: 75-96. doi: 10.1111/j.1469-7998.1962.tb01823.x

Williams WD. 1963. The ecological relationships of isopod crustaceans Asellus aquaticus (L.) and A. meridianus Rac. Proceedings of the Zoological Society of London 140: 661-679. doi: 10.1111/j.14697998.1963.tb01992.x

Wittenberg R. (ed). 2005. An inventory of alien species and their threat to biodiversity and economy in Switzerland. CABI Bioscience Switzerland Centre report to the Swiss Agency for Environment, Forests and Landscape. The environment in practice no. 0629. Federal Office for the Environment, Bern. $155 \mathrm{p}$.

Wittfoth AKJ, Zettler ML. 2013. The application of a Biopollution Index in German Baltic estuarine and lagoon waters. Management of Biological Invasions 4(1): 43-50. doi: 10.3391/mbi.2013.4.1.06

Wouters K \& Vercauteren T. 2009. Proasellus coxalis sensu auct. (Crustacea, Isopoda) in a lowland brook in Heist-op-den-Berg: first record in Belgium. Lauterbornia 67: 53-61.

Zamora-Muñoz C, Alba-Tercedor J. 1994. Asellus aquaticus (L.) en la Penínsila Ibérica. Limnética 10(2): 2-7.

Editorial responsibility: Torkild Bakken.

This article is open-access and distributed under the terms of the Creative Commons Attribution 4.0 International license. This permits all noncommercial use, distribution, and reproduction in any medium, provided the original work is properly cited.

(http://creativecommons.org/licenses/by/4.0/). 
Appendix I. Identification Guide to Asellus aquaticus Linnaeus, 1758, Proasellus coxalis Dolfus, 1892 and Proasellus meridianus Racovitza, 1919.

The known distribution patterns of the three species of non-cave-dwelling Asellidae in Europe, as of 2019, are shown in Figure A1. The new records of $P$. coxalis and $P$. meridianus in the Nordic countries are marked in the figure.
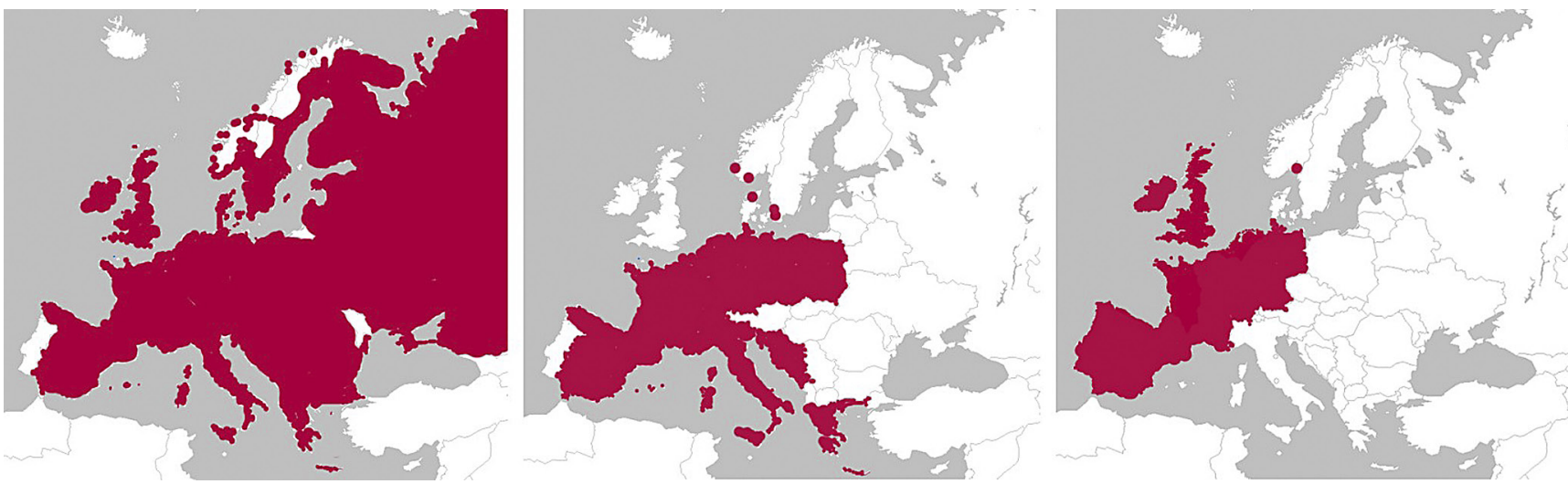

Figure Al. Distribution of Asellidae in Europe. From left: Asellus aquaticus, Proasellus coxalis and Proasellus meridianus. The figures are based on GBIF (2019). New information is added for P. meridianus (Spain: Zamora-Muñoz \& Alba-Tercedor 1994, Switzerland: Wittenberg (ed.) 2005), $P$. coxalis (Denmark: Siegel 2019, Switzerland: Wittenberg (ed.) 2005) and A. aquaticus (Spain: Zamora-Muñoz \& Alba-Tercedor 1994, Eastern Europe: Sworobowicz et al. (2015), in addition to information given in this paper. (Note that non-European records are not shown.)

The guide is based on Wouters and Vercauteren (2009), Spikkeland et al. (2013), Gledhill et al. (1993) and personal observations. (Note on body size - A. aquaticus and P. meridianus mature sexually above $5 \mathrm{~mm}$ in length (Gregory 2009), so this guide should be used with caution for specimens below this size). Individuals photographed for the identification guide in this paper originated from the rivers Glomma and Tista in Østfold (south east Norway) and Stokkalandsvatnet (south west Norway).

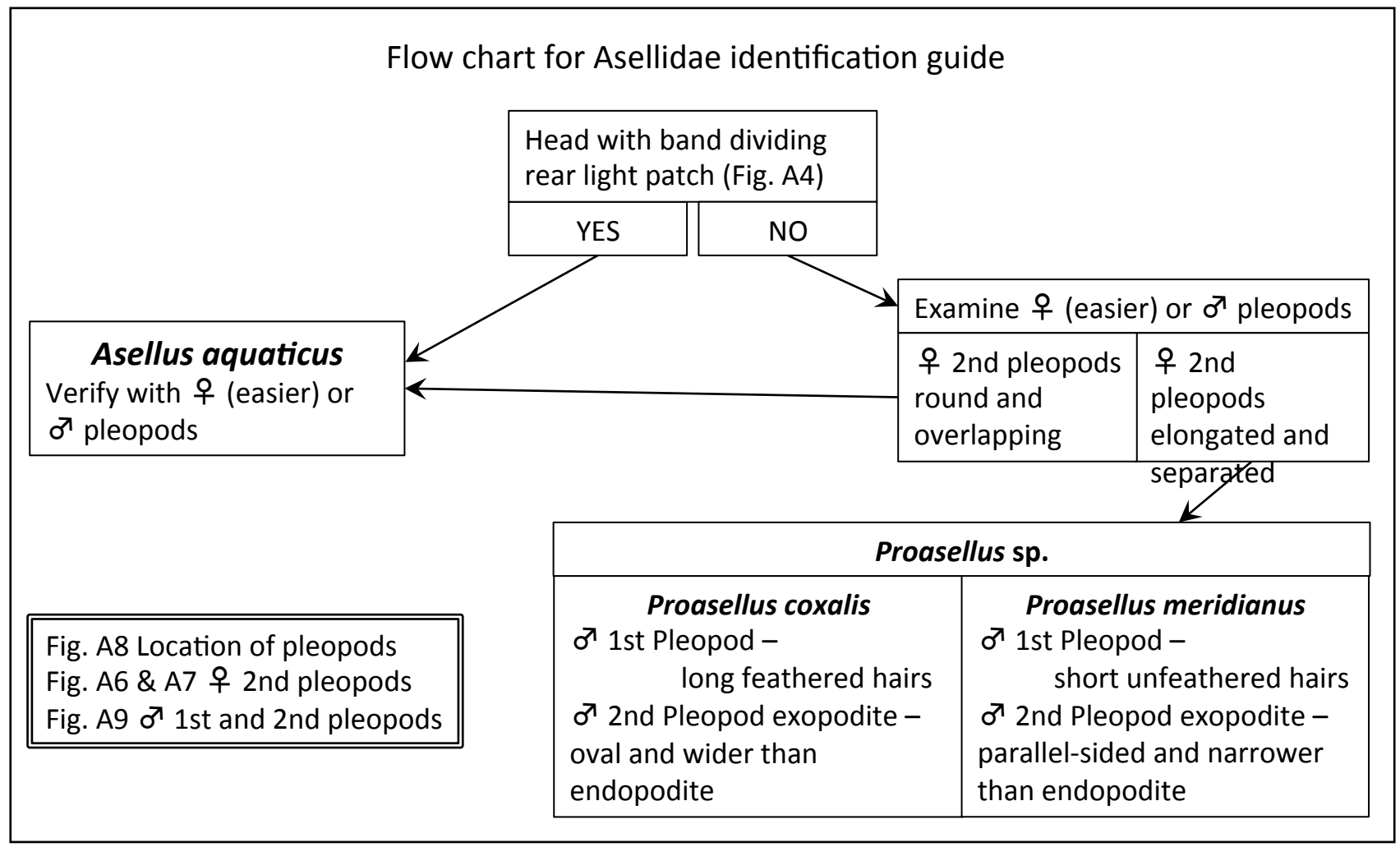

Figure A2. Flow chart of the most reliable features for identifying the three species of Asellidae.

Figure A3 shows the three species. (Note that a number of legs and other appendages have fallen off.) Although there are differences in body colour between the three species (Wouters and Vercauteren 2009), it is highly variable and is not a very useful diagnostic criterion, especially after preservation. 


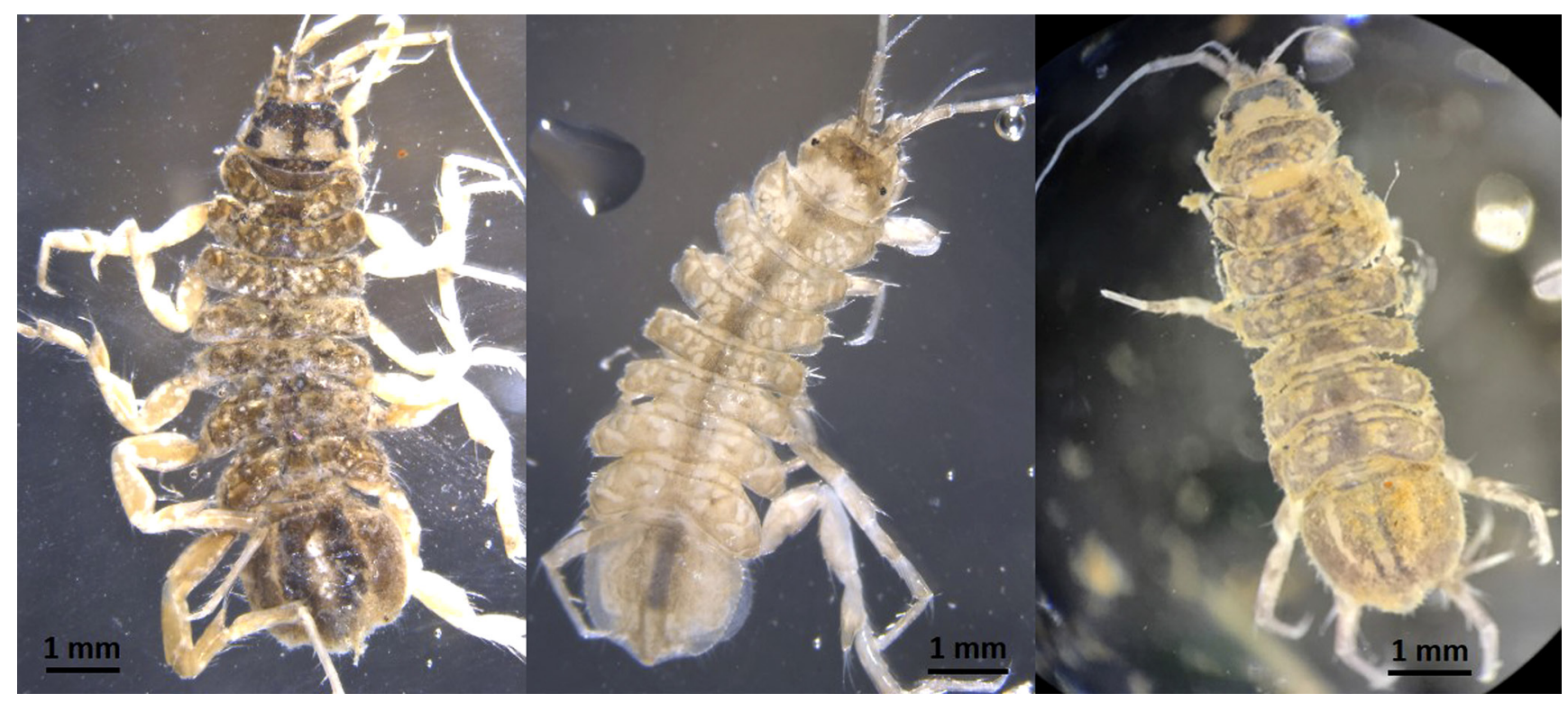

Figure A3. General appearance of the three species. Asellus aquaticus (left), Proasellus coxalis (middle) and Proasellus meridianus (right).

\section{$\underline{\text { Head pattern }}$}

Asellus aquaticus - Lighter area at back of head sub-divided into two patches by median, darker, band.

Proasellus coxalis - lighter area at back of head a single light-coloured patch. Border between darker and lighter areas indistinct, with the margin often having lighter spots.

Proasellus meridianus - lighter area at back of head a uniformly light-coloured patch. Edge of patch of colour sharply delineated.

Head pattern (Figure A4) provides the most useful, quick clue to species identification, although it should not be relied on alone. The A. aquaticus head pattern is usually diagnostic. An undivided light patch at the back of the head, however, could belong to any three of the species (particularly in small or poor quality individuals) and the border of the light patch in P. meridianus is often indistinct, not sharply delineated, (Figure A5).

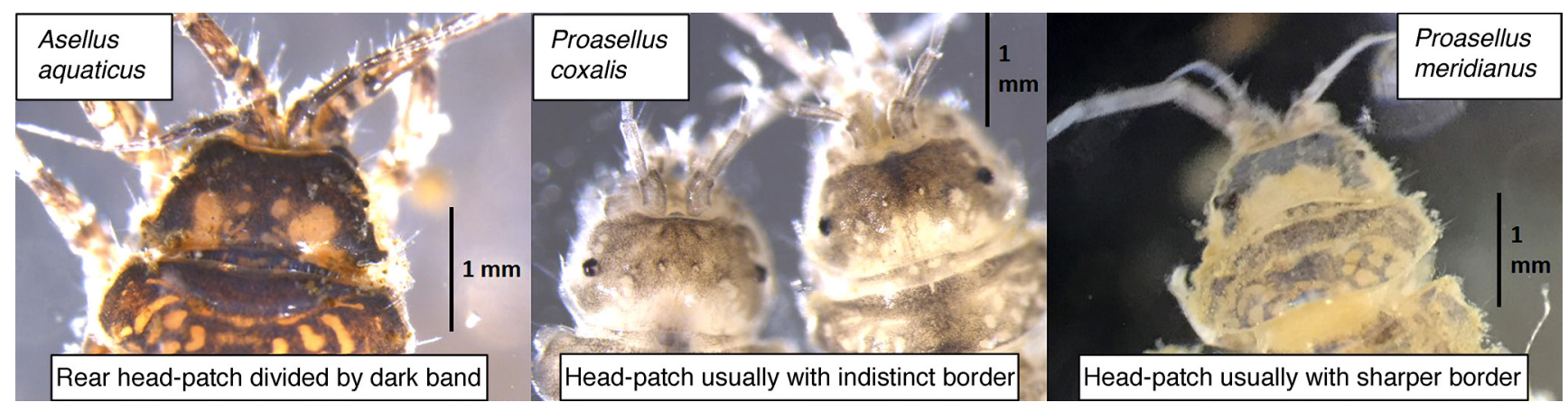

Figure A4. "Textbook" head pattern.

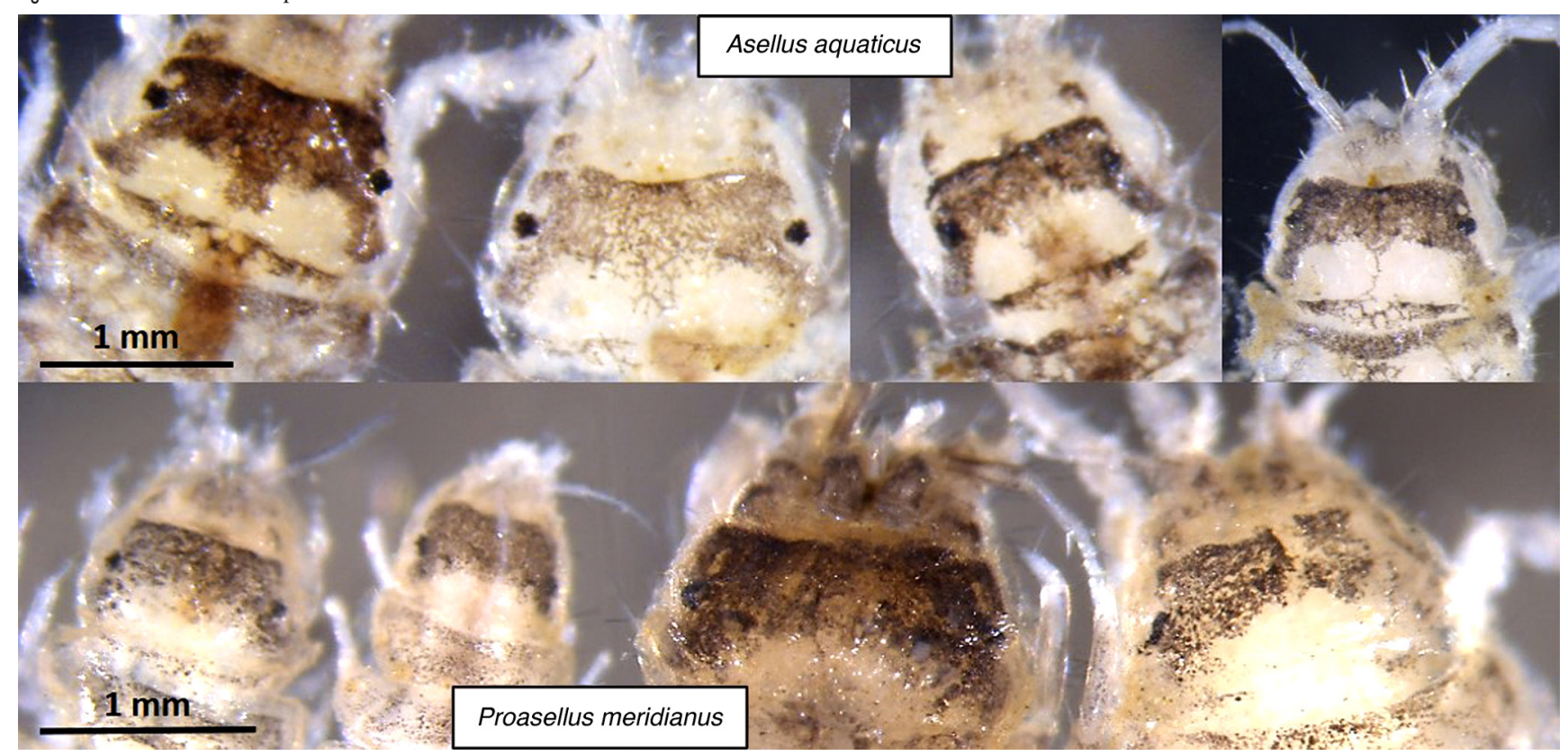

Figure A5. Head pattern variability in Asellus aquaticus (top) and Proasellus meridianus (bottom). 
Female 2nd pleopod (first is missing in female)

A definitive and obvious difference between the very common A. aquaticus and the two Proasellus species is the female pleopod 2 (Figure A6 and A7) (see Figure A8 for the location of the pleopods and to compare with male). The female 2nd pleopods of P. coxalis and P. meridianus are very similar, however, and then the male pleopods must be examined.

There appear to be subtle differences between 2nd female pleopods in P. meridianus versus $P$. coxalis. In P. meridianus, it appears to be slightly blockier with a widely rounded tip, whereas in $P$. coxalis it has a more gracefully rounded and tapering appearance and a more narrowly rounded tip (Figure A7). In P. meridianus the inner-most hair is further round the inner edge than in $P$. coxalis, meaning that it points both rearwards and distinctly inwards. The inner hair of $P$. coxalis points rearwards with little or no inwards direction. These differences are also evident in the diagrams of Grüner (1965), although not mentioned in the text. However, the reliability and utility of these characters would need to be tested with a systematic examination of numerous individuals before they are proposed as a serious criterion to separate the species.

Asellus aquaticus - second pleopod round and left and right overlap

Proasellus meridianus and coxalis - second pleopod elongated and tapering. Left and right lie neatly side by side.

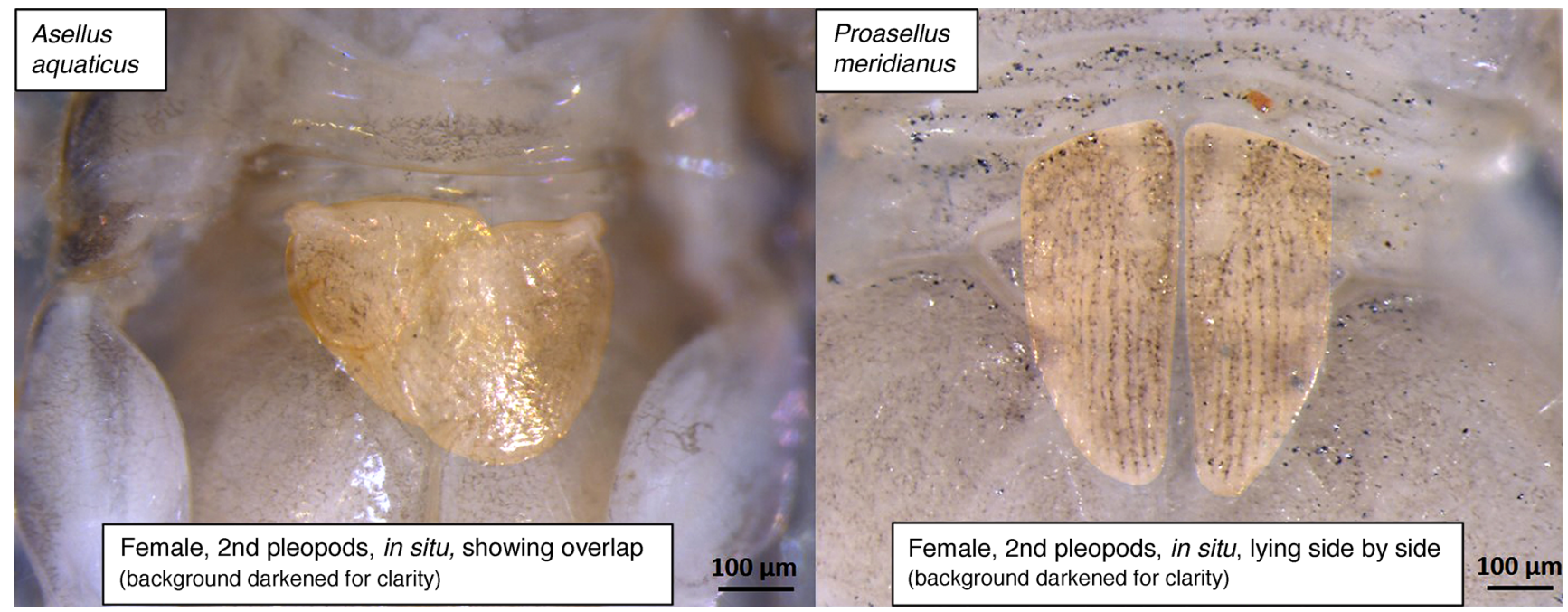

Figure A6. Female 2nd pleopods, in situ.

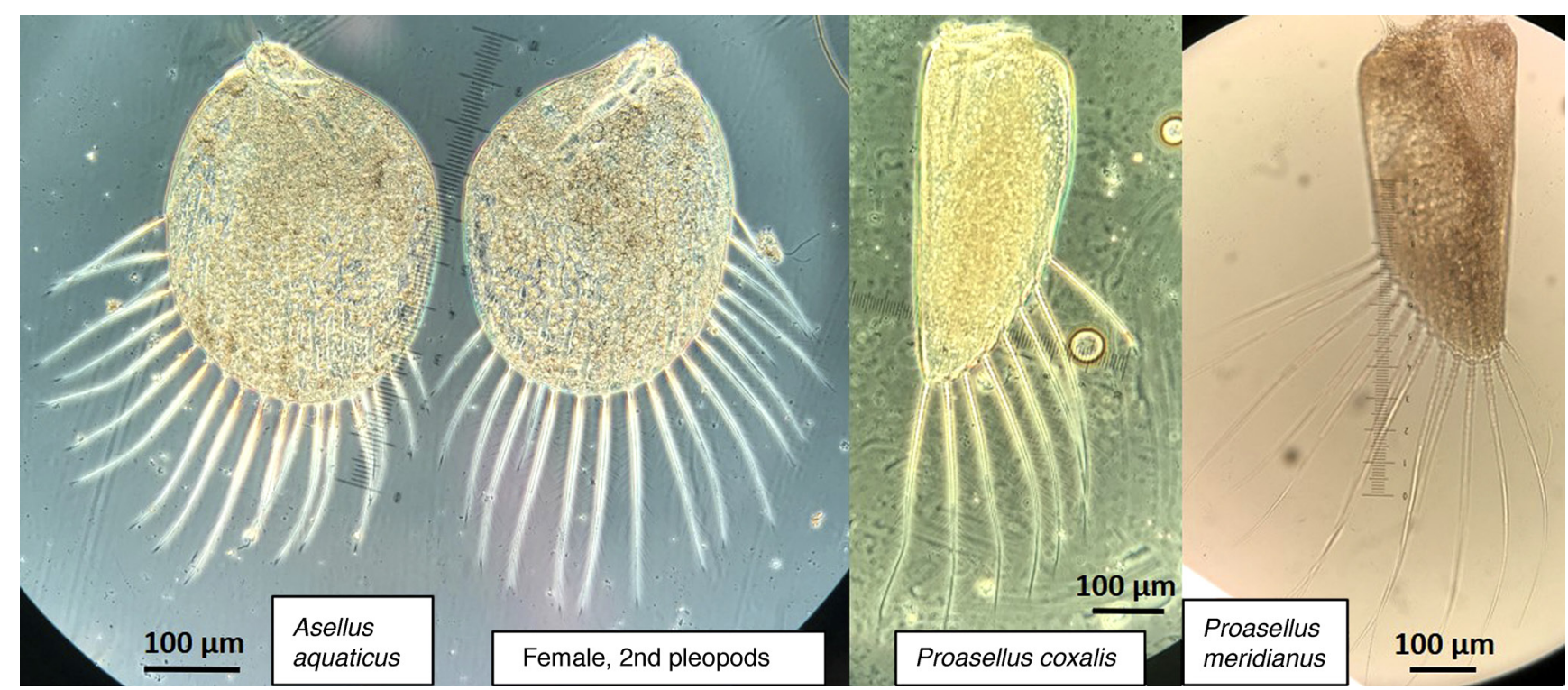

Figure A7. Female 2nd pleopods. 


\section{Male 1st and 2nd pleopods}

Figure A8 shows the area of the animal where the pleopods are located and the pair of copulatory styles, which are only present in males and not females. Figure A9 shows the differences in between the pleopods of the three species. These are the most reliable criteria for species identification.

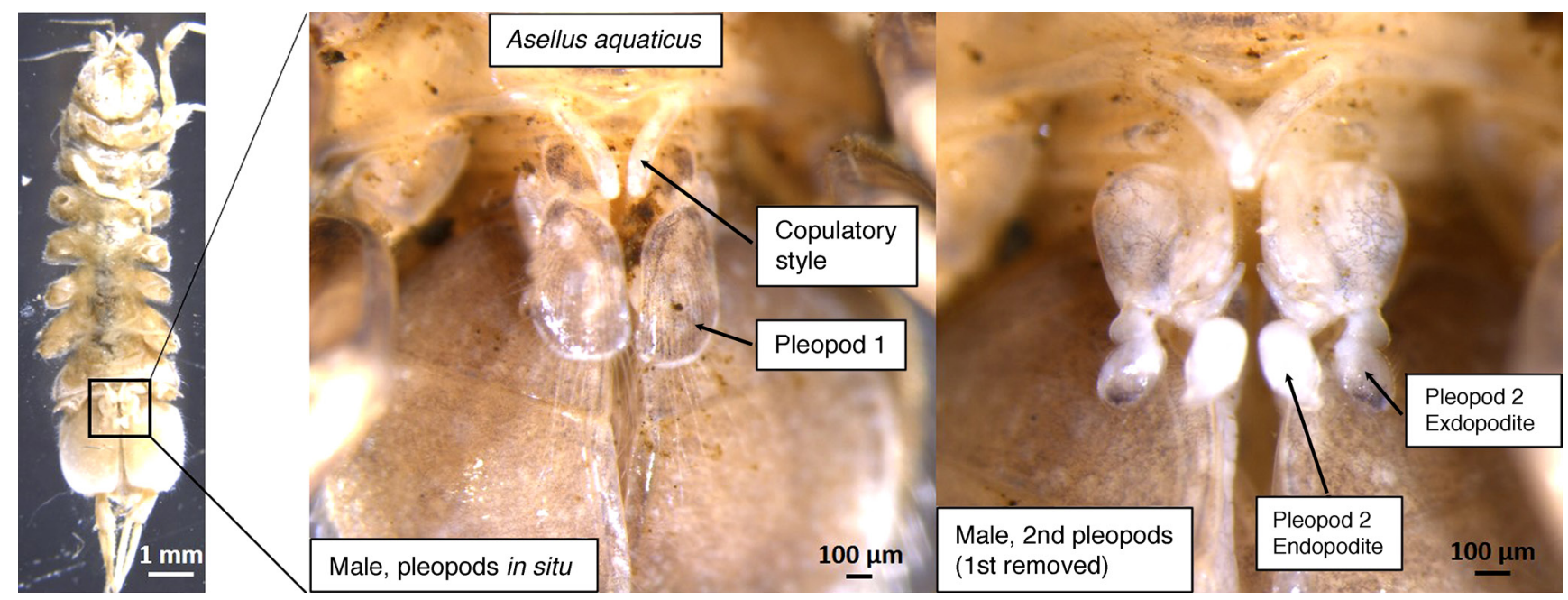

Figure A8. Asellus aquaticus - location of male reproductive appendages, appearance in situ.

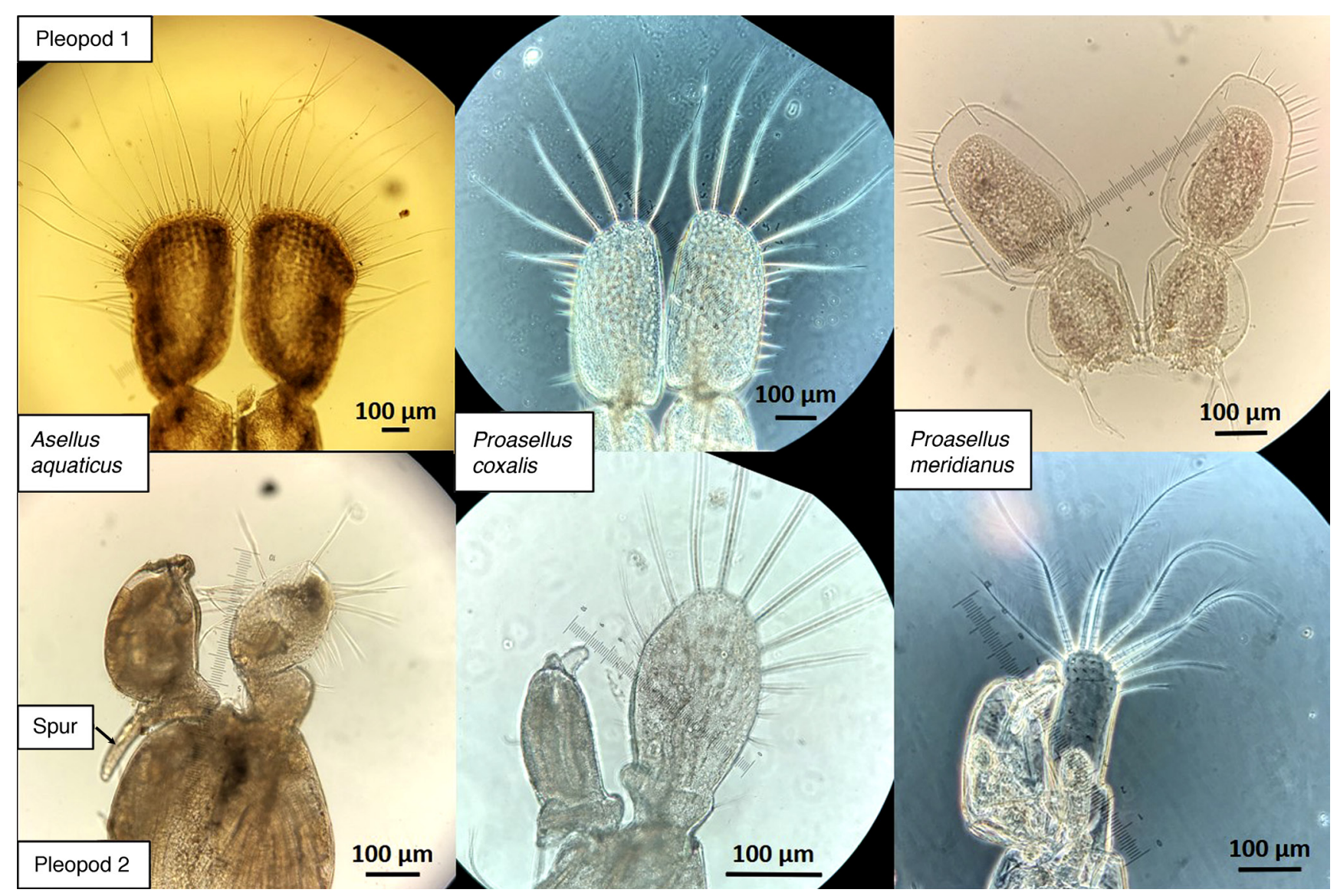

Figure A9. 1st and 2nd male pleopods. Pleopod 2: endopodite left and exopodite right of each picture.

\section{Male 1st pleopod (Figure A9)}

Asellus aquaticus - first pleopod large, predominantly covering 2nd pleopod. Distal and outer margin with long, feathered hairs. Notch on outer margin.

Proasellus coxalis - first pleopod small with long, feathered hairs on outer margin. Partially covering pleopod 2.

Proasellus meridianus - first pleopod small with shorter, unfeathered hairs on outer margin. Partially covering pleopod 2. 


\section{Male 2nd pleopod (Figure A9)}

Asellus aquaticus - exopodite rounded and shorter than endopodite. Unfeathered hairs on outer edge of distal segment of exopodite. Longer, feathered hairs on inner edge. Each inner hair has the feathering pointing proximally in the proximal half and distally in the distal half. This is also clearly shown in a diagram in Grüner (1965). In Grüner (1965) these hairs are drawn straight, but in each specimen examined for this study these hairs had a tendency to kink near the middle (Figure A10). Whether this is also true in life is not known. Spur at base of inner margin of endopodite (Figure A9).

Proasellus coxalis - Exopodite oval, longer and wider than the endopodite and with long marginal feathered hairs. Fringe of dense, shorter, fine hairs on inner margin of exopodite visible at high magnification.

Proasellus meridianus - exopodite elongate and parallel-sided, rounded at the tip with long, feathered hairs. Endopodite always wider and shorter than exopodite.

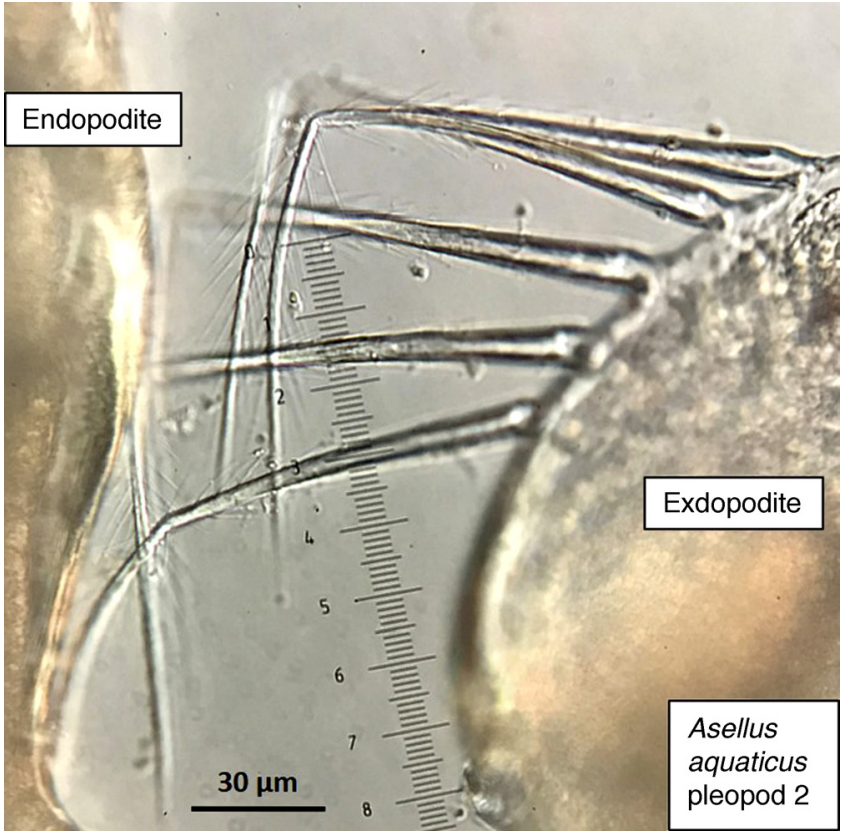

Figure AlO. Asellus aquaticus male pleopod 2. Close-up to show kinked, feathered hairs on inner edge of exopodite. Feathering pointing proximally below the kink and distally above the kink.

Male 1st pereopod (first thoracic leg) (Figure A11)

Asellus aquaticus - penultimate distal segment of leg with triangular-shaped outline to ventral margin. Note that this difference can be subtle, even in larger specimens.

Proasellus meridianus and $\boldsymbol{P}$. coxalis - penultimate distal segment of leg with gently curved outline to ventral margin.

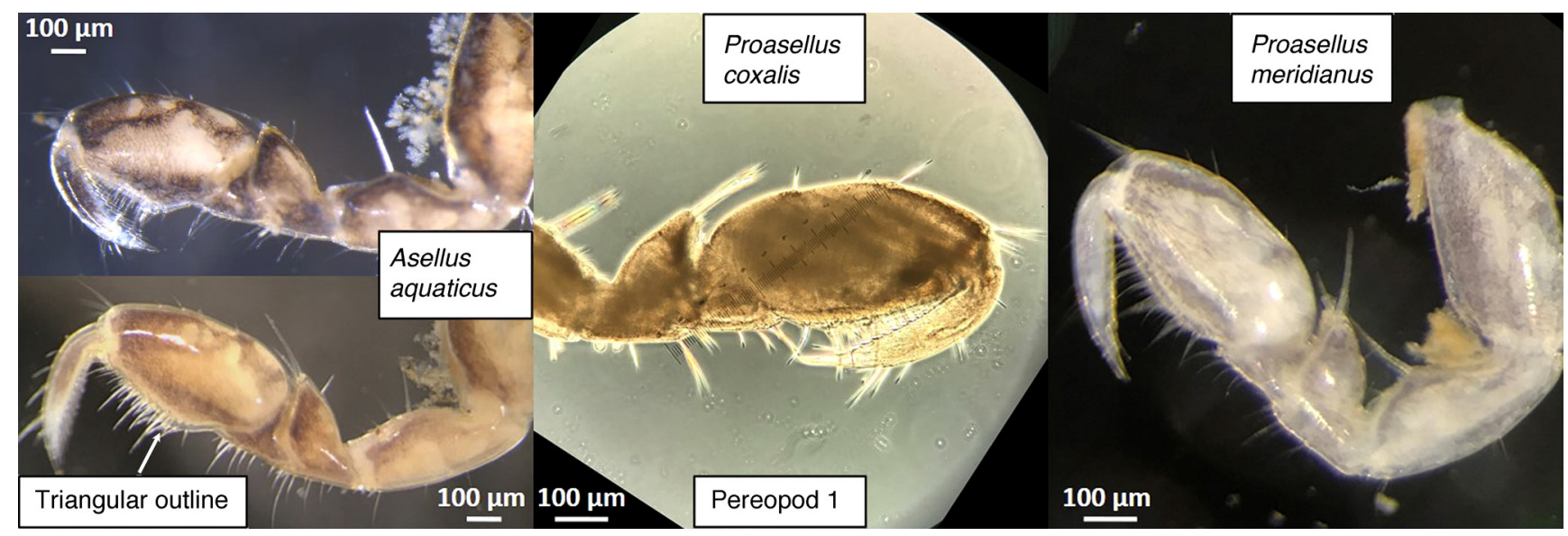

Figure All. Male 1st pereopod. 